GLOBAL WATER PATHOGEN PROJECT

PART THREE. SPECIFIC EXCRETED PATHOGENS: ENVIRONMENTAL AND EPIDEMIOLOGY ASPECTS

\title{
ENTAMOEBA HISTOLYTICA
}

\section{Layla Ben Ayed}

National Institute of Agronomy, Tunis

Tunis, Tunisia

Sonia Sabbahi

Institut National de Recherche en Génia Rural, Eaux et Forêts

Tunis, Tunisia 


\section{Copyright:}

\section{cc) (i) (2) \\ BY SA}

This publication is available in Open Access under the Attribution-ShareAlike 3.0 IGO (CC-BY-SA 3.0 IGO) license (http://creativecommons.org/licenses/by-sa/3.0/igo). By using the content of this publication, the users accept to be bound by the terms of use of the UNESCO Open Access Repository (http://www.unesco.org/openaccess/terms-use-ccbysa-en).

\section{Disclaimer:}

The designations employed and the presentation of material throughout this publication do not imply the expression of any opinion whatsoever on the part of UNESCO concerning the legal status of any country, territory, city or area or of its authorities, or concerning the delimitation of its frontiers or boundaries. The ideas and opinions expressed in this publication are those of the authors; they are not necessarily those of UNESCO and do not commit the Organization.

\section{Citation:}

Ben Ayed, L., and Sabbahi, S. (2017). Entamoeba histolytica. In: J.B. Rose and B. Jiménez-Cisneros (eds), Water and Sanitation for the 21st Century: Health and Microbiological Aspects of Excreta and Wastewater Management (Global Water Pathogen Project). (R. Fayer and W. Jakubowski (eds), Part 3: Specific Excreted Pathogens: Environmental and Epidemiology Aspects - Section 3: Protists), Michigan State University, E. Lansing, MI, UNESCO. https://doi.org/10.14321/waterpathogens.34

Acknowledgements: K.R.L. Young, Project Design editor; Website Design: Agroknow (http://www.agroknow.com)

Last published: October 18, 2017 


\section{Summary}

Entamoeba histolytica is an invasive, pathogenic protozoan, causing amoebiasis, and an important cause of diarrhea in developing countries. Our understanding of its epidemiology has dramatically changed since this amoeba was distinguished from another morphologically similar one, Entamoeba dispar, a non pathogenic and commensal parasite. These two species can now be distinguished mainly through molecular and immunological procedures.

The life cycle of the parasite is represented by two forms: the cyst and the trophozoite. The cyst is the infective and non motile form of the parasite. It is excreted in the feces and can survive for weeks in the environment. Mature cysts possess 4 nuclei and average $20 \mu \mathrm{m}$ in diameter. The trophozoite is the motile form, with a size ranging from 10 to $60 \mu \mathrm{m}$. It colonizes the intestinal tract leading mainly to tissue destruction and secretory bloody diarrhea.

Amoebiasis is basically an acute disease acquired by: (i) ingestion of cysts present in contaminated food, water, or plants, (ii) through person to person contact, (iii) exposure in endemic areas, and (iv) swimming in contaminated water. Clinical manifestations range from the asymptomatic carrier state to dysenteric symptoms represented by abdominal pain and bloody diarrhea.

The organism can be prevalent in cold regions as well as tropical and subtropical regions that have contaminated water. In fact, E. histolytica is an important cause of morbidity and/or mortality wherever sewage facilities are inadequate. As is the case for other intestinal protozoan pathogens, wastewater treatment techniques are reported not to be very efficient for E. histolytica elimination possibly because of their resistance to disinfectants and the small size of the cysts. Stabilization ponds have been reported to be more effective than activated sludge for their abatement. Sedimentation and filtration can enhance the removal of cysts from wastewater.

\section{Entamoeba}

World Health Organization reported that Entamoeba histolytica affects approximately 500 million people worldwide, resulting in symptomatic diseases in 50 million and mortality in 100,000 persons (Lozano et al., 2012). About $80-90 \%$ of infections are asymptomatic and are likely due to the nonpathogenic species E. dispar or $E$. moshkovskii, therefore the worldwide incidence of $E$. histolytica is, more likely, estimated to be 5 million cases annually, with global mortality still at 100.000 persons per annum. Very young persons, pregnant women, recipients of corticosteroids, and malnourished individuals appear more susceptible than others to amebic colitis. Entamoeba species are single cell organisms with two life cycle stages.
Cysts are directly excreted in the stool and spread through the environment via contaminated water, soil, and fresh vegetables as well as unsanitary household conditions. Species cannot be differentiated based on cyst or trophozoite morphology. Following ingestion, cysts transform into vegetative forms or trophozoites, the motile stage that moves with the aid of pseudopodia and colonize the intestinal mucosa of the large bowel. Damage to the colon is caused by neutrophils that respond to infection from E. histolytica. Trophozoites can also invade the intestinal mucosal barrier and, via the bloodstream, disseminate to the liver, lung, and other sites with resultant pathologic manifestations. Drug treatments are available. Lagoons and constructed wetlands, sedimentation, filtration, flocculation, chemical and ultraviolet disinfection have all been employed for removal of cysts from water with varying degrees of success.

\subsection{Epidemiology of the Disease and Pathogen(s)}

\subsection{Global Burden of Disease}

\subsubsection{Global distribution}

More than any other causes, parasitic diseases are contributing significantly to the burden of illnesses, leading sometimes to death, and affecting people in developing and in developed world, even in regions that include highincome countries (WHO, 2008).

Amebiasis is a major cause of morbidity and mortality worldwide, mostly in tropical and sub-tropical countries characterized by inadequate health services and sanitation infrastructure (Fotedar et al., 2012). The majority of deaths are a consequence of severe complications associated with intestinal or extra-intestinal invasive disease.

Approximately 4 to $10 \%$ of the carriers of this amoeba infection develop clinical symptoms within a year and amoebic dysentery is considered as the third leading cause of death from parasitic disease worldwide after Malaria and Schistosomiasis (Mortimer and Chadee, 2010; Ghasemi et al., 2015).

Although all deaths could be due to invasive $E$. histolytica infection, data on the prevalence of $E$. histolytica might be an overestimation because the data come from a date in time before the separation of the pathogenic $E$. histolytica from the non pathogenic species. E. dispar and E. moshkovskii both might contribute to the prevalence figures (Diamond and Clark, 1993; Tengku Shahrul et al., 2012).

Since 1986 and through the published data regarding the frequency of infection and disease caused by $E$. histolytica, Walsh (1986) indicated that $10-20 \%$ of the world's population was infected by this parasite, among them $1 \%$ developed the invasive form of the disease. The morbidity rate, estimated at that time, was around 100.000 inhabitants per annum. Later on and according to the WHO reports, E. histolytica was reported affecting approximately 500 million people worldwide, resulting in symptomatic 
diseases and death of about 50 million and, as stated earlier before, 100,000 persons respectively (WHO, PAHO, UNESCO, 1997). However, since $80-90 \%$ of the infections remain asymptomatic as they are due to the non pathogenic protozoa E. dispar or E. moshkovskii, the worldwide incidence of $E$. histolytica is, more likely, estimated to be 5 million cases annually, with global mortality still at 100.000 persons per annum (Jackson, 1998).

During the last decade, Entamoeba moshkovskii became relevant because of its ability to infect humans. For a long time, it was considered to simply be a free-living amoeba. However, in the last decade it was found associated with gastrointestinal symptoms (Shimokawa et al., 2012). It is frequently found in regions with a high prevalence of amebiasis (Heredia et al., 2012).

A high prevalence of E. moshkovskii infections was identified in Bangladesh, by Ali et al. (2003). A prevalence of $21.1 \%$ with $E$. moshkovski was observed among children between 2 and 5 years of age; $15.6 \%$ had E. histolytica infection. The fact is that infection with E. moshkovski is not uncommon and has a higher prevalence than infection with E. histolytica. The same was found in India (Parija and Kairnar, 2005), in homosexual patients with gastrointestinal symptoms in Australia (Fotedar et al., 2008), in two healthy adults in Tunisia (Ben Ayed et al., 2008a), and in a cohort of HIV-suspected or confirmed patients in Tanzania (Beck et al., 2008). All these studies also highlighted the important prevalence of $E$. moshkovski mono infection.

Several outbreaks worldwide caused by the presence of $E$. histolytica have been reported associated with sewage contamination. In the United States no outbreaks have been recorded in the last 30 years; 6 waterborne and foodborne outbreaks occurred between 1946 and 1980 (Lippy and Waltrip, 1984). The most dramatic outbreak in the US was in Chicago in 1933 with 1000 cases including 58 deaths, due mainly to defective plumbing which linked sewage contamination to the drinking water (www.fda.org). Another overflow of sewage water into the drinking water system affected more than 1400 persons in Sweden in Christmas 1986 (Anderson and de Jong, 1989). In 1993, 730 students acquired amebiasis from contaminated underground well water at a private school in Taiwan (Chen et al., 2001). A large waterborne outbreak was reported in Tbilisi, in the former Soviet Republic of Georgia resulting from deficiencies with surface water filtration (Barwick et al., 2002). At the time of the outbreak, Tbilisi's population was advised to boil the drinking water and the city brought some modifications to the water treatment process: (i) the improvement of the coagulation step, (ii) the increase of the chlorine doses and (iii) the reduction of the filtration velocities (United Nations Economic commission for Europe, 2003), nevertheless 106 residents developed hepatic abscess cases. In 1988, 42 Italian tourists in Thailand acquired infections with E. histolytica and Giardia after consuming drinks with ice, ice cream, and raw fruit in ice (de Lalla et al., 1992).

E. histolytica presence and the kind of amebiasis manifestations are cosmopolitan in their distribution: amoebic liver abscess is the major form of amebiasis in South Africa, while, in Egypt, in central and South America, Africa and Asia, intestinal invasive manifestation is the predominant form (Ravdin et al., 2003).

In Vietnam (Region of Hué), for behavioral reasons, the incidence rates of amebic liver abscess were remarkably high, with reported values of approximately 21 cases per 100.000 inhabitants; coincidental with $11 \%$ of $E$. histolytica infection. In fact, in this area, a higher level of alcohol consumption was remarked with an important flies' passive food contamination (Blessmann et al., 2002).

In Mexico, amebiasis ranks fifth or sixth annually among the 20 major causes of disease (www.dgepi.salud-gob.mx). The incidence reported there was ranging from 1000 to 5000 and 615.85 to 1228.8 cases per 100.000 inhabitants annually respectively for the period of 1995 to 2000 and from 2002 to 2006 (Ximenez et al., 2009).

Asymptomatic E. histolytica infection in Egypt has been high (> 21\%), whereas asymptomatic infection in South Africa and Côte d'Ivoire has been between 0 and $2 \%$ (Stauffer et al. 2006). In Tunisia, it has ranged between 0.85 and $1.86 \%$ (Chaker et al., 1995; Fathallah et al., 2004) with approximately 2.15 cases /year in the northern part of the country reported on diarrheic persons (Bouratbine et al., 2003). These figures are similar to those from other developing countries where sanitation infrastructure and health education are lacking or are not adequate. These associations explain why resource-poor nations carry the bulk of the world's disease (Pritt and Clark, 2008).

The US national death certificate data from 1990 to 2007 identified 137 deaths from amebiasis with higher mortality rates in males, older individuals, Hispanics and Asians. Given their large population, their sizable number of immigrants and their proximity to endemic area (Mexico, Latin America, etc.), California (36.27\%) and Texas (22.16\%) had the highest numbers of deaths among the thirty states identified with amebiasis fatalities (Gunther et al., 2011).

The biochemical, immunological and genetic separation of $E$. histolytica from the non pathogenic species, provided accurate epidemiologic data in endemic areas and found that E. dispar was up to 10 times more prevalent in asymptomatic patients than E. histolytica (Huston and Petri, 1999; Solaymani-Mohammadi et al., 2006).

In an urban refugee camp in Dhaka, Bangladesh, asymptomatic infection with $E$. histolytica was $4.2 \%$ and $E$. dispar was $13 \%$ in children between 2 and 5 years of age (Haque et al., 2006). The same situation was found in Aracaju, Brazil where E. histolytica was $1 \%$ whereas $E$. dispar was $13 \%$ in analyzed cases (Lawson et al., 2004). In Northeastern Brazil, Pinheiro et al., (2004) reported the absence of E. histolytica while E. dispar was prevalent in $74.19 \%$ of cultured positive samples based on PCR. In an isolated area of the Ecuador, E. histolytica was $18.9 \%$ whereas E. dispar was $70.3 \%$ based on isoenzyme analysis (Gatti et al., 2002). In northern Ghana, a high prevalence of 
the E. histolytica/E. dispar complex (39.8\%) was found by microscopy. However, the confirmed prevalence of $E$. histolytica, through PCR, was low (Verweij et al., 2003), as it was also found in Côte d'Ivoire (Heckendorn et al., 2002) and Ethiopia (Kebede et al., 2003). Entamoeba histolytica was prevalent between 0.5 and 38\% in India (Léger and Danis, 1995). However, in this subcontinent, using molecular biology, the prevalence of the pathogenic protozoa was affirmed in $3.5 \%$ of the $11.7 \%$ hospitalized persons with amebiasis who were previously diagnosed by microscopy (Khairnar et al., 2007).

In Saudi Arabia, amebiasis poses a common and significant public health problem mostly among children. In Jeddah during the period of December 1995 to October 1996, the prevalence of E. histolytica was found to be $2.2 \%$ of 576 fecal samples collected from children aged between 0 and 5 years and suffering from acute diarrhea (el Sheikh and el Assouli, 2001). In Makkah, $70 \mathrm{Km}$ from Jeddah, $70.5 \%$ of intestinal parasitic infection was detected; and the E. histolytica/E.dispar complex was the most common one between March and November 2005 (Al Harthi and Jamjoom, 2007). Between March and August 2007, E. histolytica/E. dispar was detected at a prevalence rate of $8.3 \%$ in inpatients and $5.9 \%$ in outpatients of two major public hospitals in Jeddah (Al Braiken, 2008). Between July 2010 and 2011, children suffering from E. histolytica gastroenteritis represented $20 \%$ of the 1325 admitted cases (Hegazi et al., 2013). Confirmation was mainly based on the results of an antigen detection test that proved to have better sensitivity and specificity than traditional microscopic examination of stool samples. Authors attributed the increased prevalence recorded at the same locality (Jeddah) from 2007 (8.3\%) to 2010 (20\%) to the type of domestic water used because most cases diagnosed with higher rates drank water from wells designated for drinking water or from home tanks used for other purposes. However, patients who used desalinated water for these purposes were reported to have the lowest degree of exposure to amebiasis (Omar et al., 1995).
To determine the prevalence of E. histolytica in food handlers in Tunisia, an epidemiological study was conducted from 2002 to 2005 on 4266 fresh stool samples. By microscopy, 12 samples were found positive for the presence of $E$. histolytica/E. dispar, meaning that $2.8 \%$ were harboring it. The DNA amplification of the SSU rDNA confirmed the presence of the non pathogenic E. dispar in 11 of the samples (Ben Ayed, 2008b).

In Human Immunodeficiency Virus (HIV) patients in countries such as Colombia, Mexico, Ethiopia, Taiwan and South Africa, E. histolytica was present in 13\%; 25.3\%; $10.3 \% ; 5.8 \%$ and $12.4 \%$ of $\mathrm{HIV}^{+}$patients, respectively (Florez et al., 2003; Hailemariam et al., 2004; Moran et al., 2005; Samie et al., 2006; Hung et al., 2008).

\subsubsection{Symptomatology}

Amebiasis has been defined as the pathological conditions arising from harboring the protozoan parasite Entamoeba histolytica, with or without clinical manifestation (WHO, PAHO, UNESCO, 1997). In fact, there has been no correlation established between infection with Entamoeba dispar, E. coli and E. hartmanii and gastrointestinal symptoms. Parija and Khaimar (2005) reported gastrointestinal symptoms in Indian patients infected by the association of E. dispar with E. moshkovskii. A similar pathogenic potential was reported by Fotedar et al. (2008) and Pritt and Clark (2008).

Entamoeba polecki has been very rarely implicated as a cause of diarrhea and E. gingivalis is associated with peridontal disease (Salaki et al., 1979; Lucht et al., 1998).

Clinical features of amebiasis range from asymptomatic colonization or non invasive disease $(80-90 \%$ of the infections) to amoebic colitis (dysentery or diarrhea) and invasive extra-intestinal disease, manifested most commonly in the form of liver abscesses (Fotedar et al., 2007) as summarized in Table 1.

Table 1. The three main kinds of the disease manifestations of amebiasis (Aristizabal et al., 1991; Seeto and Rockey, 1999; Petri and Singh, 1999)

\begin{tabular}{|c|c|c|}
\hline Non invasive disease & Invasive disease & Extra-intestinal disease \\
\hline $\begin{array}{l}\text { Amoeba colony on mucosa } \\
\text { surface }\end{array}$ & Necrosis of mucosa leading to ulcer & Metastasis via blood stream or direct extension \\
\hline $\begin{array}{l}\text { - Asymptomatic cyst excreter } \\
\text { - Self resolve in few months }\end{array}$ & $\begin{array}{c}\text { Amebic colitis }=\text { dysentery }= \\
\text { inflammation of the lining of the } \\
\text { colon : } \\
\text { - Diarrhea with occult or gross blood } \\
\text { resulting in anaemia } \\
\text { - Gradual onset of abdominal pain } \\
\text { and tenderness } \\
\text { - Weight loss }\end{array}$ & $\begin{array}{c}\text { Primarily liver abscess, most commonly affected } \\
\text { organ through the transport of trophozoites from } \\
\text { the large intestine via blood vessels leading to : } \\
\text { - Several weeks of fever } \\
\text { - Right upper quadrant pain, } \\
\text { - Absence of concurrent dysentery. } \\
\text { - Prominent weight loss } \\
\text { - Leukocytosis }\end{array}$ \\
\hline
\end{tabular}




\begin{tabular}{|c|c|c|}
\hline Non invasive disease & Invasive disease & Extra-intestinal disease \\
\hline $\begin{array}{l}\text { - No dysenteric diarrhea } \\
\text { - Other abdominal symptoms }\end{array}$ & $\begin{array}{l}\text { - Occasional ameboma } \\
\text { - Colonic lesions vary from mucosal } \\
\text { thickening to flask shaped } \\
\text { ulcerations to necrosis of the } \\
\text { intestinal wall. }\end{array}$ & $\begin{array}{l}\text { Infection of other sites less frequent : lungs, } \\
\text { brain, etc. }\end{array}$ \\
\hline Presence of E. histolytica in stool & $\begin{array}{c}\text { Diagnosis is reliable when there is } \\
\text { detection of E. histolytica antigens in } \\
\text { stool }\end{array}$ & $\begin{array}{c}\text { Amoeba-free stools and common antibodies of } E \text {. } \\
\text { histolytica are present in the patients serum }\end{array}$ \\
\hline $\begin{array}{l}\text { Equally distributed between } \\
\text { genders }\end{array}$ & Different between age groups & Ten times more common in men than women \\
\hline
\end{tabular}

Disease can be caused after ingestion of even a small number of mature cysts.

1.1.2.1 Asymptomatic or non-invasive disease

Asymptomatic infection is defined as the presence of $E$. histolytica in stool in the absence of colitis or extraintestinal infection.

Most infections do not exhibit overt clinical manifestations and are self resolved in few months. But, when they occur, for almost one disease case per four asymptomatic intestinally infected individuals (Ali et al., 2008), they are insidious and intermittent, commencing as abdominal discomfort and tenderness, bloating, irregular bowel habits, dysentery with or without blood/mucous, tenesmus with bloody mucoid diarrhea without fecal leukocytes, constitutional symptoms, toxic megacolon and finally symptoms and signs of peritonitis secondary to perforation (Haque et al., 2006). Moreover, the non invasive disease could persist or progress to an invasive one in which trophozoites penetrate the intestinal mucosa (Haque et al., 2003).

1.1.2.2 Invasive disease

In the invasive disease, trophozoites kill epithelial cells and invade the colonic epithelium leading to a gradual onset of abdominal pain and tenderness, weight loss, and diarrhea with bloody stools (Speelman et al., 1987).

Amebiasis is the fourth greatest cause of mortality and the third greatest cause of morbidity by protozoa worldwide (Ximenez et al., 2009). The clinical syndrome associated with this disease is an amebic colitis resulting in a flask shaped ulcer. During this invasive stage, trophozoites, with ingested erythrocytes, replicate at a high rate in the host tissues. However, in the tissue lesions, cysts production decrease and are never found (www.garlandscience.com).

Unusual manifestations of amebic colitis include acute fulminant or necrotizing colitis with abdominal pain and distension accompanied by rebound tenderness, which usually requires surgical intervention to prevent mortality (Hamano et al., 2008). E. histolytica infection can also occasionally result in the formation of an amebic granuloma or ameboma, which is an inflammatory thickening and granulation of the intestinal wall around the ulcer mimicking colonic cancer in appearance (Petri and Singh, 1999).

\subsubsection{Extra-intestinal disease}

E. histolytica is a facultative pathogen, exhibiting a wide range of virulence including the ability to metastisize to other organs, leading to extra-intestinal amebiasis. The liver is the most commonly affected organ through access via the portal venous system. Because it receives the bulk of the venous drainage from the right colon, the right lobe of the liver is 4 times more likely to be involved than the left lobe (Salles et al., 2003). Complications of amebic liver abscess include its rupture and secondary bacterial infection (Petri and Singh, 1999). The collection of pus in the liver as an abscess may present acutely, with fever and right upper abdominal tenderness, and subacutely, also with abdominal pain and prominent weight loss (Shandera et al., 1998). Moreover, the skin and the white of the eyes become yellow or jaundiced. It is assumed that it is closely related to a history of alcohol abuse.

Hematogenous spread of trophozoites to other sites, such as lungs or brain is rare but does occur. The second most common extra-intestinal site, after the liver, is the lungs. Pulmonary infections follow direct extension of the hepatic lesion across the diaphragm and into the pleura. Amoebic brain abscess results when E. histolytica trophozoites invade the central nervous system via the bloodstream, and is frequently lethal (Maldonado-Barrera et al., 2012). In Tunisia, Bouali et al. (2014) diagnosed 3 cases of amoebic cerebral abscess: 2 men aged respectively 33 and 43 years and one woman aged 56 years who were successfully operated on. Among these three important manifestations, another rare form is cutaneous amebiasis, arising as a complication of amoebic dysentery (Lamps, 2010), usually deriving from contaminated skin or a continuous contact with exudates containing virulent trophozoites (Bumb and Mehta, 2006).

\subsection{Taxonomic Classification of the Agent(s)}

\subsubsection{Taxonomy}

Entamoeba histolytica was first described as Amoeba coli by Lösch in 1875 after the stool diagnosis of a mortal dysentery case and took its present name in 1903 (Ravdin, 1995).

It is classified in the domain of Eukarya, kingdom of 
Protista, phylum of Sarcomastigophora, and the subphylum of Sarcodina, which contains both free-living and parasitic members. Sarcodines of the class Rhizopodea and the subclass Lobosea, undergo locomotion and feeding using pseudopods. This protozoan belongs to the order Amoebida, the family Endamoebidae and the genus Entamoeba. Among the eight species of human intestinal amoeba $(E$. histolytica, E. dispar, E. moshkovskii, E. hartmanii, E. Bangladeshi, E. polecki also called E. chattoni, E. hartmanni and E. gingivalis), Entamoeba histolytica is the only pathogen and the others are considered non pathogenic and rarely cause disease in humans (Verweij et al., 2001). However, Shimokawa et al. (2012) showed that E. moshkovskii induced diarrhea, bloody stool and weight loss in susceptible mice and diarrhea in Bangladeshi children. This is emphasizing the pathogenicity of this protozoan. In consequence, two Entamoeba species could be considered pathogenic: E. histolytica and E. moshkovskii.

On the other side, E. histolytica is morphologically identical to E. moshkovskii and E. dispar in both the appearance of the cysts and trophozoites stages. These similarities were initially recognized by Brumpt (1925), but he was ignored until 1978 when tremendous advances in immunology, biochemistry and genetics proved that $E$. histolytica consisted of two species: an invasive pathogen (E. histolytica) and non invasive species (E. dispar) (Diamond and Clark, 1993).

The acquired virulence of $E$. histolytica is based on its ability to secrete enzymes and proteases, enabling it to penetrate the colon mucosa through the invasion of epithelial cells and subsequently interfering with the host's humoral immune response (Anaya-Velazquez and PadillaVaca, 2011). This pathogenic amoeba is a single cell organism that can replicate in the large intestinal tract by binary fission division. Phylogenetically, E. histolytica is located on one of the lowermost branches of the eukaryotic tree. Thus, it is different from higher eukaryotes by its inability of de novo purine synthesis and its lack of glutathione. It also uses pyrophosphate instead of ATP at several steps of glycolysis (McLaughlin and Aley, 1985; Bruchhaus et al., 1996) and has a unique alcohol-aldehyde reductase (Flores et al., 1996). However, it shares, with higher branching eukaryotes, mitochondrial genes that are enclosed within a biochemically inert remnant organelle (Mai et al., 1999). Additionally, comparing to the others eukaryotes, E. histolytica possesses in the RNA polymerase II promoter a GAAC element, which is a novel conserved sequence specific to the rate and the size of mRNA transcription (Singh et al., 1997).

E. histolytica has 8,197 genes, a genome of $20.6 \mathrm{MB}$ size containing six isoenzymes (http://www.apiindia.org/medicine_update_2013), helping it mainly in the lysis of tissues and the digestion of food material and intra-luminal cellular debris (Willhoeft and Tannich, 1999).

\subsubsection{Physical description of the agent}

Among the species infecting humans and colonizing the intestine, three (E. histolytica, E. dispar and E. moshkovskii) are morphologically identical in both their cysts and trophozoites. Concerning E. bangladeshii, its similitude with the three aforementioned, was only reported for the trophozoite form (Royer et al., 2012).

E. histolytica has a typical fecal-oral life cycle composed of dormant quadric nucleate cysts eliminated in feces (Figure 1) and invasive trophozoites that replicate in the intestine (Figure 2).

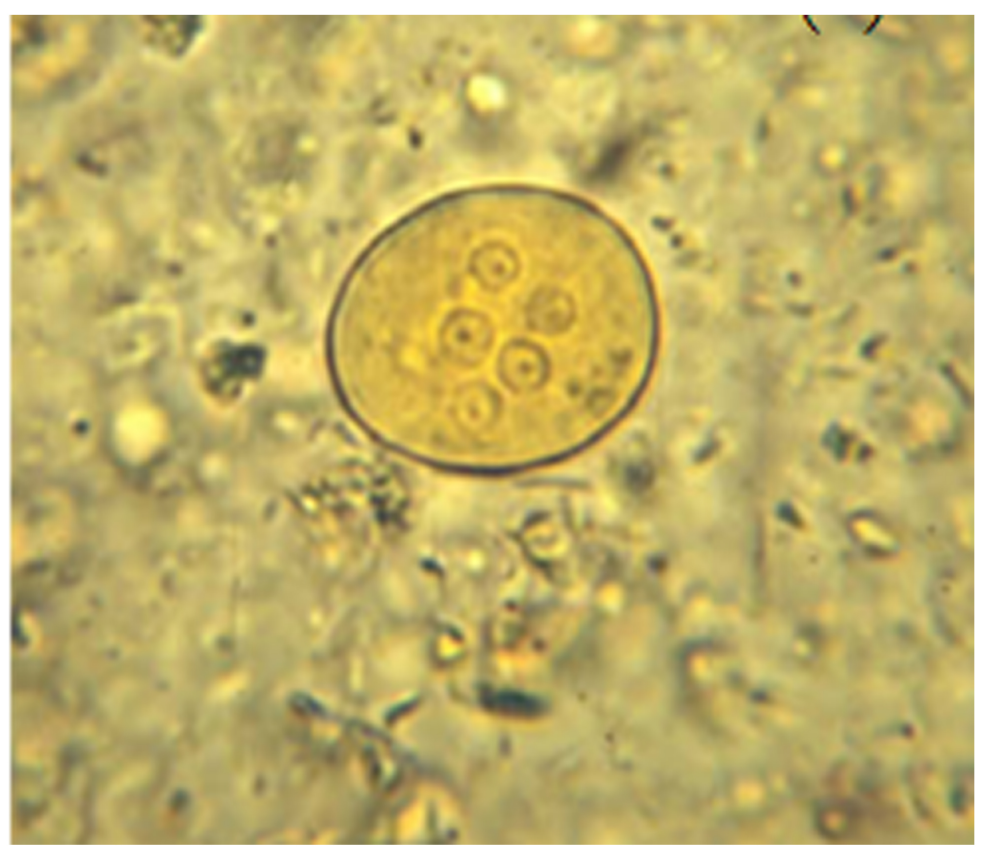

Figure 1. Cyst of E. histolytica/ E. dispar/ E. moshkovskii in raw water samples stained with iodine (www.dpd.cdc.gov.DPDx) 


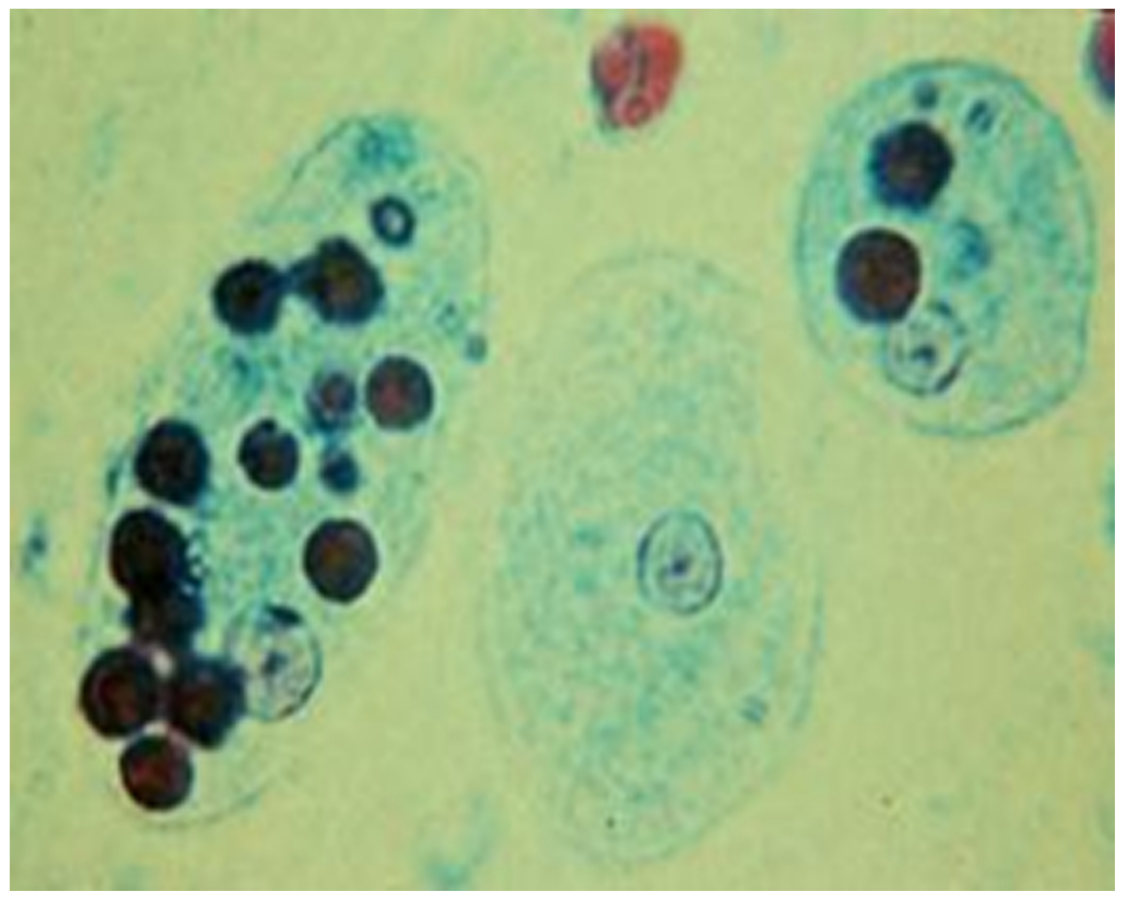

Figure 2. Trichrome stain of E. histolytica trophozoites in amebiasis (www.dpd.cdc.gov.DPDx)

The cyst is the infective, non motile form which undergoes excystation during its progression in the gastrointestinal tract. Mature cysts possess 4 nuclei, have an average diameter of $20 \mu \mathrm{m}$, a chitin composed wall that appears smooth and refractile when viewed by light microscopy and which contains glycogen deposited in a vacuole and ribosomes that are often aggregated to form elongated bars. These cysts are directly excreted in the stool (Samie et al., 2006).

Vegetative forms or trophozoites are the motile stage that moves with the aid of pseudopodia, formed by the flow of ectoplasm followed by endoplasm and allowing them to move at a speed of $5 \mathrm{~mm} / \mathrm{s}$ (Kvgk, 2011). Pseudopodia tend to be the broad blunt type, called lobopodia (Subclass of
Lobosea). Trophozoites are characterized by an amorphous shape with an average diameter ranging between 15 and $30 \mu \mathrm{m}$, a rough endoplasmic reticulum or Golgi bodies, helices arranged ribosomes, and an absence of a classical mitochondria (Lohia, 2003).

Upon ingestion, these motile forms can colonize the intestinal mucosa of the large bowel.

Indeed, this vegetative stage could be represented by two forms: (i) the minuta or precystic stage and (ii) the histolytica trophozoite or magna stage as illustrated in Figure 3.

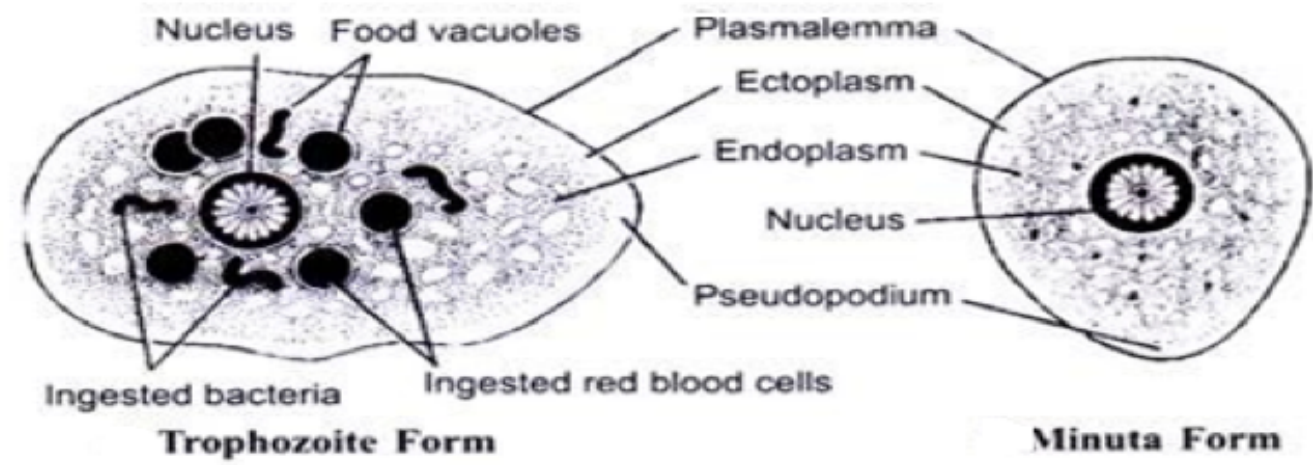

Figure 3. The two types of E. histolytica vegetative form (http://www.biologydiscussion.com/parasites)

- The minuta form (10 à $15 \mu \mathrm{m})$ is an intermediate stage between the trophozoite and the mature cyst and is characterized by a clear ectoplasm, a granulate endoplasm containing phagocyted bacteria and a central karyosome (Schuster and Visvesvara, 2004). It is not pathogenic, and normally lives in the lumen of the intestine and is rarely found in tissues. It undergoes encystation and contributes to the transmission from one host to another. This form is mainly present in asymptomatic and convalescent patients.

- The histolytica form is bigger (25 à $40 \mu \mathrm{m}$ ) and 
contains in its endoplasm, in addition to the spherical and central nucleus, food vacuoles, phagocytized bacteria, and red blood cells (Stanley, 2003). It inhabits the anterior part of large intestine.

These forms are present in at least two species: $E$. dispar and E. histolytica, which are morphologically indistinguishable unless the latter is observed with ingested red blood cells (erythrophagocystosis) (Roberts et al., 1973).

\subsubsection{Life cycle}

Entamoeba histolytica is monogenetic or monoxenous, meaning that its life cycle is completed only in one host, which is usually humans, and does not need an intermediate host. However, non human primates, some other animals like monkeys have been infected with $E$. histolytica (Verweij et al. 2003; Regan et al. 2014).

The ingestion of infective mature cysts (possessing 4 nuclei), from contaminated food, water, or hands, is followed by their excystation only when they reach the terminal part of the small intestine (Ileum). The gastric juice has no effect and cannot dissolve the chitinous cyst wall. This ingestion is unfortunately, of a daily occurrence in most developing countries (Haque et al., 2003).

Excystation is the process of transformation of the cysts into trophozoites by disruption of the cyst wall, through the trypsin enzyme action, allowing the quadric-nucleated amoeba to emerge and to start proliferation. The amoeba undergoes a round of nuclear division followed by 3 successive rounds of cytokinesis (cell division) to produce 8 small uni-nucleated trophozoites, called amebula. Under hostile conditions, they could also produce cysts, once they aggregate to the intestine mucin layer and by accumulating a considerable amount of food in the form of glycogen, black rod-like chromatid granules, and by forming a thin, rounded and resistant cyst wall. Thus, encystation occurs in the intestine lumen, and cyst formation is complete when four nuclei are present. The signals leading to encystation or excystation are poorly understood, but research on the reptilian parasite Entamoeba invadens suggested that encystation might be trigged by ligation of a surface galactose-binding lectin to the surface of the parasite (Cho and Eichinger, 1998). After that, both stages are passed in the feces: trophozoites are usually present in loose stool, whereas cysts are found in firm stools. Because of the protection conferred by their walls, cysts are able to resist environmental conditions for days to weeks and can be responsible for disease transmission. However, once outside the body, trophozoites passed in the stool are rapidly damaged, and if ingested do not survive exposure to the gastric environment (Eichinger, 2001). The foregoing describes the typical asymptomatic colonization, accounting for almost 80 to $90 \%$ of all infections.

In 10 to $20 \%$ of infections, when the trophozoites colonize the intestine by adhering to colonic mucin glycoprotein via a galactose and N-acetyl D-galactosamine (Gal/galNac)-specific lectin (Göttke et al., 1998), they feed on bacteria and cellular debris and undergo repeated rounds of binary division. Damage to the colon is caused by neutrophils that respond to the invasion. The trophozoites may also invade the intestinal mucosal barrier and gain access to the bloodstream, whereby they can disseminate to the liver, lung, and other sites with resultant pathologic manifestations. From these sites they cannot leave the host (Solaymani-Mohammadi and Petri, 2008). 
Figure 4 details the E. histolytica life cycle in humans after ingestion of cysts for both kinds of infections: the asymptomatic (non invasive) accounting for almost 80 to
$90 \%$ of cases and the invasive one accounting for 10 to $20 \%$ of cases.

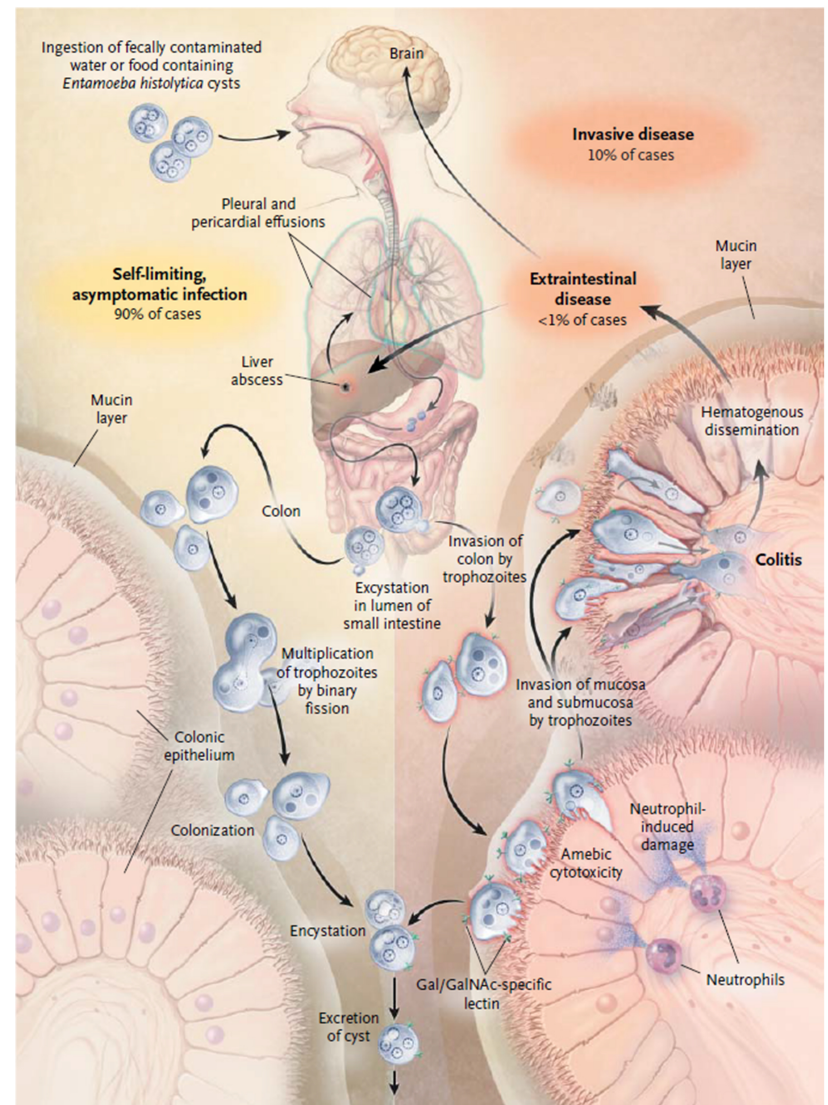

Figure 4. E. histolytica life cycle (from Haque et al., 2003)

\subsection{Transmission}

\subsubsection{Routes of transmission}

Knowing the routes of transmission provides comprehension of how the disease is disseminated. Interventions aimed at the prevention and the control of these routes can reduce the incidence, the prevalence of diarrheal illness, and the economic impacts.

Amebiasis manifestations range from mild to severe or toxic and the course of the infection may vary in different communities based on disparities in development, standards of living, sanitation, use of stagnant water, place of residence, intense fly breeding, number of rooms and bedrooms per house, being infected by other parasites, the nutritional status, and age of infected persons (Stauffer et al., 2006). Individuals in houses with less than five rooms had amebiasis with greater infection risk compared to those living in houses with more rooms (Benetton et al., 2005). Prevalence of E. histolytica infection could also be higher among members of family eating with their fingers or at the same plate (Oyerinde et al., 1979).

In South Africa, a cross sectional study of stool and seroprevalence in children in a community with treated water supply and a rural site with minimal sanitation detected an important difference between them. Counterintuitively, the children living in the first community harbored both parasites (E. histolytica and E. dispar) whereas those in the rural community harbored only $E$. dispar with a high rate, more than $50 \%$. Jackson et al. (2000) suggested that: (i) host genetics, (ii) strain differences, and (iii) competition between the two parasites could potentially account for this striking difference.

Basically, amebiasis is acquired, like most enteric protozoa, by the ingestion of cysts present in contaminated water or food. They can survive for weeks in inadequately treated sewage/sewage products. Livestock and domestic pet handling are potential sources (Fletcher et al., 2012).

The weather can impact prevalence of infections. Extreme events such as excessive rainfall, floods, and droughts impact their abundance in the environment (Jaykus et al., 2009) by the increase of the runoff or the flush of animal manure and wildlife or pets droppings into surface or ground water (Moreno, 2006). Extreme weather events can also decrease water treatment effectiveness.

The foodborne and waterborne transmission remain the primary sources of infection despite ongoing investment in 
better sanitation infrastructure, water quality and environmental protection legislation (Bridge et al., 2012). Food can become contaminated at several stages: during production, harvesting, handling, transport, and preparation processes. The risk of foodborne transmission is increased when food is consumed raw or undercooked (Benetton et al., 2005). Food handlers are another possible source of infection, as are mechanical vectors such as flies and cockroaches (Schuster and Visvesvara, 2004). Contamination could also occur from cross-contamination with soiled implements, animal manure or through irrigation with contaminated water or sewage and with the use of biosolids as fertilizers or soil conditioners (Dawson, 2005; Mohamed et al., 2016).

To reduce the negative public health effects of amebiasis, Amuta et al., (2008) proposed education of the general population to stop eating raw or undercooked foods, to wash fruits and vegetables, and to wash hands before eating, as well as enforcement of environmental laws. In Brazil, Benetton et al. (2005) estimated that the risk of acquiring amebiasis was 1.6 times greater among persons who ate raw vegetables than among those who do not eat raw vegetables. They also highlighted the causes of contamination and related it to the quality of the water used to wash vegetables and to habits of food preparation.

Entamoeba histolytica can also be transmitted through many water sources including drinking and recreational waters, lakes, and streams. The impact depends on the geographic location which is different throughout the world as well as within regions depending on the socio-economic status (Thompson and Smith, 2011). There is much great reliance on water from lakes and streams for drinking water in Asia and Africa whereas they are used to a greater extent for recreation in Europe.

The spread of contamination through water could be mainly attributed to: (i) a process failure within water utilities (Dawson, 2005), (ii) the sewage contamination (Ferrer et al., 2012), or (iii) the presence of basic sewerage systems or latrines (Thompson and Smith, 2011).

Wastewater and municipal sanitary workers have a higher incidence of amebiasis than the general population. An 11\% occurrence of the complex E. histolytica/E. dispar in French sewer workers (Bonnin et al., 2002), and of $E$. histolytica inform of a greater number of Vietnamese farmers engaged in wastewater-irrigated agriculture or aquaculture with highest rates in people having 2-4 hours of daily contact with wastewater versus those with less exposure (Trang et al., 2007).

In an epidemiological study among the Oran Asli communities in Malaysia, E. histolytica was associated with 6 main risk factors : (i) drinking untreated water, (ii) bathing and washing in a river, (iii) not washing hands after playing with soil or gardening, (iv) defecation in river or bush and (vi) low household income (Anuar et al., 2012). E. dispar, in addition to these 6 risk factors, was also associated with: (i) age : the children less than 15 years old where the most contaminated, (ii) outdoor sewage disposal, (iii) consuming raw vegetables and (iv) the low level of mother education. Although there were no factors associated with E. moshkovskii infection (Anuar et al., 2012), others authors (Parija et al., 2010; Yakoob et al., 2012) associated its presence with sanity conditions and lifestyles.

\subsubsection{Reservoirs}

Amebiasis is primarily a disease of humans and nonhuman primates, without a defined zoonotic reservoir. In non human primates, ingested cysts proliferate in the small intestine and are carried to the colon, where the amoeba attack the epithelial lining (Schuster and Visvesvara, 2004). Infections are usually acquired from a chronically ill or symptomatic cyst excreter (Heymann, 2008).

Humans are the only known reservoirs of Entamoeba histolytica. Infection of other mammals (apes, cats, dogs, pigs) is infrequent, as these hosts act as neither reservoirs nor sources of infection, meaning that they do not excrete cysts with their feces and therefore they can't survive outside of their bodies. No vectors are reported transmitting amebiasis.

\subsubsection{Incubation period}

The incubation period is usually 14 to 28 days, but could range from few days to months or years (Heymann, 2008).

Approximately 4 to $10 \%$ of carriers infected with $E$. histolytica develop clinical disease within a year (Stanley, 2003). Amebic liver abscess can occur years after the exposure and may follow the onset of immune-suppression (Gill and Beeching, 2004).

\subsubsection{Period of communicability}

Infected patients excrete cysts intermittently sometimes for years if not treated (American Academy of Pediatrics, 2012).

Patients who are suffering of acute amebic dysentery pose a limited danger of contamination to others due to the absence of cysts in dysenteric stools and to the fragility of the produced trophozoites (Heymann, 2008). However, persistent cyst excreter can transmit the pathogenic protozoa to household contacts years later (Vreden et al., 2000). All this information is recapitulated in Table 2. 
Table 2. Amebiasis characteristics (www.anses.fr)

\begin{tabular}{|c|c|c|c|}
\hline Incubation period & Disease & Duration of symptoms & Duration of cysts shedding \\
\hline \multirow[t]{2}{*}{ Not applicable } & Asymptomatic & Not applicable & Several months \\
\hline & $\begin{array}{l}\text { Acute colonic } \\
\text { amebiasis }\end{array}$ & $\begin{array}{c}<10 \text { days with } \\
\text { treatment. } \\
\text { (Possible evolution to } \\
\text { chronic disease) }\end{array}$ & $\begin{array}{l}\text { Several months (up to } \\
4.5107 \text { cysts/day) }\end{array}$ \\
\hline \multirow[t]{2}{*}{$2-4$ months } & $\begin{array}{l}\text { Chronic } \\
\text { colonic } \\
\text { amebiasis }\end{array}$ & $\begin{array}{l}\text { A few weeks to } \\
\text { several months }\end{array}$ & Several months \\
\hline & $\begin{array}{l}\text { Fulminant } \\
\text { necrotising } \\
\text { amoebic } \\
\text { colitis }\end{array}$ & A few days & Not applicable \\
\hline $\begin{array}{l}2-4 \text { months } \\
\text { sometimes months } \\
\text { or years }\end{array}$ & $\begin{array}{c}\text { Visceral } \\
\text { amebiasis }\end{array}$ & $\begin{array}{l}\text { A few weeks to } \\
\text { several months }\end{array}$ & Not applicable \\
\hline
\end{tabular}

\subsubsection{Population susceptibility}

A difference in amebiasis symptomatology's prevalence is reported. Very young patients, pregnant women, recipients of corticosteroids and malnourished individuals are found to be predisposed, more than others, to amebic colitis (Stanley, 2003; Anaya- Velazquez and Padilla-Vaca, 2011).

In children, important overall prevalence was recorded all over the world. In India, Kaur et al. (2002) reported 11\% of E. histolytica infections, while Ali et al. (2003) found almost the same rate $(15.6 \%)$ in preschool children in Bangladesh. Higher rates of $65.7 \%$ were reported in Nigerian children less than five years (Ogunlesi et al., 2006). As well, Hegazi et al., (2013) reported an important infection rate of amebiasis in children less than one year and they attributed this high prevalence to inadequate breast feeding.

These results are of major public health concern considering the impacts of the disease. Children infected by amebiasis showed a significant weight loss compared to those, with the same age, who were not infected (Haque et al., 2006).

Infection is also assumed to be acquired directly from infected mother to neonates. In Mexico, infection in pregnant women has been estimated between $22.5 \%$ and $35 \%$ with $15 \%$ of their children intestinally infected (Weinger and Avila, 1983).

There is also a significant difference in the prevalence of E. histolytica according to the gender even if Malaysian studies showed the opposite (Sharma et al., 2004; Zahida et al., 2010). In fact, in Turkey and in Japan, males were found more affected than females (Ohnishi and Murata, 1997; Ozyurt et al., 2007). On the other hand, other studies conducted in Turkey (Ozgumus and Efe, 2007) and in Pakistan (Ejaz et al., 2011) showed a prevalent and significant female infection. These differences could be mainly attributed to behavior (kind of work), ecological and physiological or hormonal reasons.

Although asymptomatic E. histolytica infections are equally distributed between the genders, invasive disease is more common in men (Fletcher et al., 2012), which could be associated to gender based difference in the complement system (Snow et al., 2008). Possibly, functional natural killer $\mathrm{T}$ cell levels and higher gamma interferon in females might enhance their resistance to liver abscess (Mortimer and Chadee, 2010). In particular, amebic liver abscess is 7 to 12 times more common in men than in women, with predominance among men aged between 18 and 50 years. The reason for this disparity could be attributed to the implications of hormonal effects, as the prevalence of amebic liver abscess is also increased among postmenopausal women (Samie et al., 2006).

In Nigeria, Amuta et al. (2008) assumed that the protozoa Entamoeba histolytica is having the high rates of infection $(21.6 \%)$ among the pre and post menstrual women, with no level of education as they are predisposed to contaminated water bought from water vendors who unfortunately are selling water from broken pipes or even untreated water caught directly from rivers. Almost the same infection rate $(29.47 \%)$ was encountered among females in another African country, the Chad Republic (Hamit et al., 2008).

Symptomatic intestinal amebiasis occurs in all age groups. Liver abscesses due to amebiasis are 10 times more frequent in adults than in children and most extra-intestinal amebiasis is found in persons from 20 to 50 years of age with 1 female infected for 4-6 males (Haque et al., 2003; Valenzuela et al., 2007).

In Tunisia, a retrospective study conducted between 1992 and 2005 in a university hospital in Sfax, in the southern part of the country, reported the presence of 16 cases of visceral amebiasis (Makni et al., 2007). More men were infected than women: 11 were diagnosed with liver infection and 5, between 15 and 30 years of age, with pleura-pulmonary localizations. Among the 11 cases of liver 
infections, 6 were between 50 and 80 years old.

Immuno-suppressed individuals, in particular those with Acquired Immunodeficiency Syndrome (AIDS) infection are more sensible. Higher rates of carriage have been reported in HIV/AIDS patients, who are prone to life threatening gastrointestinal manifestations (Stark et al., 2009). In South Africa, a study showed that HIV positive individuals with $\mathrm{CD}_{4}{ }^{+}$counting less than 200 cells/ $\mu$ l, were relatively more likely to be contaminated by $E$. histolytica (Samie et al., 2010).

There has been increasingly risk of amebiasis among men who have sex with men (MSM) particularly in East Asian countries such as Japan, Taiwan and South Korea, probably induced by the oral-anal sexual contact (Hung et al., 2008; Watanabe et al., 2011). In addition to HIV/AIDS, the increasing use of organ transplants represents an important risk factor for invasive amebiasis in many countries. In Colombia, for example, $24.7 \%$ of detectable anti-amoebic antibodies were revealed in organ transplant patients (Reyes et al., 2006). Ralston and Petri (2011) stated that a polymorphism in the leptin receptor increases susceptibility to amebiasis in both adults and children.

Amebiasis could also be related to the life in institutions where increased risk for amebic colitis and liver abscess was noted in mentally retarded individuals (Nagakura et al., 1989).

It is also assumed that the prevalence of E. histolytica is correlated with population density as it was reported in Gambia (Bray and Harris, 1977) and in the studies of Blessmann et al., (2002) and (2006) in Central Vietnam where the densely populated area were found with higher prevalence than in the whole city.

In developed countries, E. histolytica infections are confined to immigrants or travelers with long term stays (> 1 month) in endemic area (Hamano, 2008). In 1993, a total of 2970 cases of amebiasis were reported by the Centers for Disease Control and Prevention (CDC), among them $33 \%$ and $17 \%$ were respectively reported in Hispanic and Asian or the Pacific Islands immigrants. Freedman et al. (2006) reported rates of acute diarrhea ranging from 1.5\% in travelers returning from Southeast Asia to $3.6 \%$ in those returning from Central America, with an overall infection rate of $2.7 \%$. On the other hand, in Japan, amebiasis is mainly reported in autochthons more than in immigrants, with approximately 500 to 600 cases and 3 to 4 deaths yearly (Nozaki et al., 2006).

Besides, its distribution is also closely related to temperature and humidity. In fact, Bray and Harris, (1977) found a higher prevalence of amebiasis in the western part of Gambia, which is characterized by lower temperatures and a higher humidity, compared with the eastern part of the country.

\subsection{Population and individual control measures}

\subsubsection{Drug therapy}

Given the small but substantial risk of invasive disease and its potentiality to be transmitted to others, the WHO/PAHO recommends the treatment of all cases of proven E. histolytica regardless of symptoms (WHO/PAHO/UNESCO, 1997) given its classification as a category B priority bio-defense agent (Haque et al., 2006) and its potential for causing invasive disease (Stanley, 2003).

Several drugs are available for amebiasis treatment and their choice depends mainly on the clinical stage (Table 3). Diagnosis has to be adopted before the treatment as it differs from intestinal and invasive disease. In poor and endemic areas, the standard optimal approach adopted is the treatment of all patients with cysts and trophozoites identified on stool examination without additional tests for speciation leading to an overtreatment that will hasten the development of drug resistance in E. histolytica. Asymptomatic carries, or cysts excreters, should be treated with a luminal amebicide to minimize the spread of the disease. The luminal agents namely Paromomycin, Iodoquinol and Diloxanide furoate, strictly recommended for treatment of patients with intestinal and asymptomatic infections, are effective in eliminating cysts from the intestinal tract. When typically administrated for a 10 day course at $30 \mathrm{mg} / \mathrm{kg}$ per day (divided into three daily doses), they will reduce the risk of transmission to others (Heymann, 2008). Paramomycin has the advantage of not being absorbed in the bowel (Ravdin and Stauffer, 2005). Abdominal cramps and nausea are the most commonly reported adverse effects. 
Table 3. Drug therapy for the treatment of amebiasis (Haque et al., 2003)

\begin{tabular}{|c|c|c|c|c|}
\hline \multirow[t]{2}{*}{ Disease } & \multirow[t]{2}{*}{ Drug } & \multicolumn{2}{|c|}{ Dosage (mg/day) } & \multirow[t]{2}{*}{ Side effects } \\
\hline & & Adult & Pediatric & \\
\hline \multirow{5}{*}{$\begin{array}{l}\text { Amebic liver } \\
\text { abscess }\end{array}$} & $\begin{array}{l}\text { Metronidazole followed } \\
\text { by a luminal agent }\end{array}$ & $\begin{array}{l}750 \\
3 \text { times } \\
\text { Fol }\end{array}$ & $\begin{array}{l}\text { 35-50 mg/kg of body } \\
\text { weight } \\
\text { in } 3 \text { divided doses } \\
7-10 \text { days }\end{array}$ & \multirow{3}{*}{$\begin{array}{c}\text { Primarily gastrointestinal: anorexia, } \\
\text { nausea, vomiting, diarrhea, abdomina } \\
\text { discomfort, unpleasant metallic taste; } \\
\text { disulfuram-like } \\
\text { intolerance reaction with alcohol, etc. } \\
\text { Primarily gastrointestinal and } \\
\text { disulfuram-like intolerance reaction } \\
\text { as for metronidazole }\end{array}$} \\
\hline & $\begin{array}{l}\text { Tinidazole followed by a } \\
\text { luminal agent }\end{array}$ & \multirow{2}{*}{\multicolumn{2}{|c|}{3 times }} & \\
\hline & & & & \\
\hline & Paromomycin & $\begin{array}{r}25 \\
3 \mathrm{di} \\
\mathrm{F}\end{array}$ & $\begin{array}{l}-35 \mathrm{mg} / \mathrm{kg} \\
\text { ided doses } \\
\text { or } 7 \text { days }\end{array}$ & $\begin{array}{c}\text { Primarily gastrointestinal: diarrhea, } \\
\text { gastrointestinal } \\
\text { Upset }\end{array}$ \\
\hline & Diloxanide furoate & $\begin{array}{l}500 \\
3 \text { times a day } \\
F c\end{array}$ & $\begin{array}{l}\quad 20 \mathrm{mg} / \mathrm{kg} \\
3 \text { divided doses } \\
10 \text { days }\end{array}$ & $\begin{array}{l}\text { Primarily gastrointestinal: flatulence, } \\
\text { nausea, vomiting, pruritus, urticaria }\end{array}$ \\
\hline \multirow[t]{2}{*}{ Amebic colitis } & \multirow{2}{*}{$\begin{array}{l}\text { Metronidazole followed } \\
\text { by a luminal agent (as } \\
\text { for amebic liver abscess) }\end{array}$} & $\begin{array}{l}750 \\
3 \text { times a day }\end{array}$ & $\begin{array}{l}35-50 \mathrm{mg} / \mathrm{kg} \\
\text { in } 3 \text { divided }\end{array}$ & As for amebic liver abscess \\
\hline & & \multicolumn{2}{|c|}{ For 7-10 days } & \\
\hline \multirow{2}{*}{$\begin{array}{l}\text { Asymptomatic } \\
\text { intestinal } \\
\text { Colonization }\end{array}$} & Paromomycin & $\begin{array}{r}25 \\
3 \mathrm{di} \\
\mathrm{F}\end{array}$ & $\begin{array}{l}-35 \mathrm{mg} / \mathrm{kg} \\
\text { ided doses } \\
\text { or } 7 \text { days }\end{array}$ & $\begin{array}{l}\text { Primarily gastrointestinal: diarrhea, } \\
\text { gastrointestinal upset }\end{array}$ \\
\hline & Diloxanide furoate & $\begin{array}{l}500 \\
3 \text { times a day } \\
F c\end{array}$ & $\begin{array}{l}\quad 20 \mathrm{mg} / \mathrm{kg} \\
3 \text { divided doses } \\
10 \text { days }\end{array}$ & $\begin{array}{c}\text { Primarily gastrointestinal: flatulence, } \\
\text { nausea, } \\
\text { vomiting, pruritus, urticaria }\end{array}$ \\
\hline
\end{tabular}

Metronidazole is not effective against cysts (American Academy of Pediatrics, 2012). It is a higher effective tissue amoebicide and is used in the treatment of invasive amoebic disease, with 5 to 10 days course at $750 \mathrm{mg}, 3$ times a day (Gonzales et al., 2009) as it is readily absorbed into the bloodstream.

To author's knowledge, no amebiasis vaccine has been approved for human clinical trials to date, but many recent vaccine development studies hold promise. Current limits to the vaccine development are: (i) incomplete understanding of human and animal models immunity mechanisms of the disease, (ii) the requirement of cellular immune responses against the ameba to assure a protection against the liver abscess (Zhang et al., 1994) and (iii) the lack of well-studied intestinal models of infection.

\subsubsection{Hygiene}

Amebiasis is common in developing countries. In order to prevent the infection or its spread to others, good practices, when living or visiting these areas of poor sanitation have to be respected and strictly followed. The major difference with other diseases transmitted by the fecal-oral route is that humans are the only host for $E$. histolytica with an absence of zoonotic transmission. The prevention has to rely on the interruption of this major way of contamination.
Control for general individuals is mainly based on: (i) washing the hands often with soap and water after using the toilet and before eating or preparing food, (ii) avoiding eating raw food, (iii) avoiding eating raw vegetables or fruit that you did not wash and peel yourself, Benetton et al. (2005) reported a harbor risk of 1.7 of $E$. histolytica/E.dispar in participants who didn't treated the water they drank by boiling or filtering or chlorinating, (iv) avoiding consuming milk or other dairy products that have not been pasteurized, (v) drinking only bottled or boiled water or carbonated drinks in cans or bottles as cysts are resistant to low doses of chlorine or iodine (Petri and Singh, 1999). Natural water can be made safe by filtering it through a 1 micron or less filter and dissolving iodine tablets in the filtered water. Moreover, there should be a: (i) sanitary disposal of fecal matter, (ii) perfect sanitation and protection of water and vegetables from pollution, (iii) protection of foods and drinks from houseflies, cockroaches, etc. and (iv) monitoring of the contacts and families in amebiasis patients by testing the presence of cysts or trophozoites in their stools..

Duc et al. (2011) highlighted the importance of hand washing. They reported significant lower risk in Vietnamese farmers handling animal excreta and washing instinctively their hands with soap compared to those who didn't handling it and are not washing their hands.

With regards to wastewater or sludge workers, the 
body, the hands and the face must be protected by: (i) making the personal aware of the potential risks and infections because of the nature of samples that are handled, (ii) wearing boots and work clothes and using a personal protective equipment, (iii) changing them before going to home, wash and leave them on site, (iv) not submerging the hands below the top of the gloves, (v) never touching face, mouth, ears, eyes or nose while working and (vi) eating only in the areas allowed to that in the plant.

According to the WHO guidelines (WHO, 2006) and to the Tunisian regulation (NT 106.03), when the treated wastewater is reused in agriculture, appropriate control measures must be rigorously respected such as: (i) the wearing of waterproof boots, gloves and of a whole combination by the farmer when he irrigate or harvest as already cited for wastewater and sludge workers or handlers, (ii) the use of the drop by drop irrigation, a technique judged better than aspersion (iii) the throwing of any fruits fallen down of the tree and in direct contact with the soil irrigated by wastewater, (iv) taking children or pets away from the irrigated perimeter as some farmers could live in the same agricultural area where they are working in.

\subsection{Environmental Occurrence and Persistence}

\subsection{Detection methods}

Diagnosis of amebiasis requires the demonstration of the presence of $E$. histolytica cysts or trophozoites in feces or colonic mucosa of patients. Nowadays, several techniques (Direct, biochemical or molecular) are used for E. histolytica detection such as microscopy, amoeba culture coupled with isoenzyme, serology, antigen detection, molecular analysis, etc. depending on the kind of the disease diagnosed (Table 4).

Table 4. E. histolytica diagnosis depending on the disease kind (www.garlandscience.com; Gonzalez-Ruiz et al., 1994)

\begin{tabular}{lc}
\hline \multicolumn{1}{c}{ Kind of disease } & Diagnosis \\
\hline & Presence of cysts and/or trophozoites in stools \\
The confirmation of the presence of E. histolytica is correlated with the detection of \\
hematophageous trophozoites \\
Antestinal disease \\
Molecular tools \\
Detection of lesion \\
Biopsy \\
$\begin{array}{l}\text { Extra-intestinal (Hepatic) } \\
\text { disease }\end{array}$ \\
Abscess aspiration : Microscopic examination of trophozoites \\
Trophozoites at abscess wall \\
Reddish brown liquid
\end{tabular}

As the pathogenic E. histolytica have similar morphological aspect with the non pathogenic species: $E$. dispar and E. moshkovskii, this section will be mainly focus on the approaches used to characterize and to distinguish the true pathogenic parasite. There is no standardized method for the detection of Entamoeba cysts. Traditionally and before the discernment between the non pathogenic and the pathogenic species, microscopy was the only reliable diagnosis technique for fresh or fixed stool samples. According to the WHO, screening by light microscopy alone, should be reported as E. histolytica/ E. dispar/ E. moshkowiskii. However, since their differentiation, the diagnosis of amebiasis by microscopic identification in stool was described as insensitive and unable to distinguish the invasive parasite $E$. histolytica from the commensal one even if their trophozoites are more likely to contain ingested erythrocytes than E. dispar (Diamond and Clark, 1993). This phenomenon is unfortunately rare in clinical samples (Fotedar et al., 2007).

Two other major approaches could also be used to detect E. histolytica and E. dispar: one based on the detection of parasite antigen in stool samples (Haque et al., 2000) and the other on amplification of DNA sequences species specific, which could be directly extracted from cultured trophozoites, using different modalities of PCR techniques (Standard methods, PCR-SHELA, real time PCR, etc.) (Roy et al., 2005; Khairnar and Parija, 2007).

Haque et al. (1997) highlighted the risks of relying 
one's analysis only on microscopy after that of all the children in Bangladesh diagnosed by microscopy with amebiasis, only $40 \%$ were positive by antigen detection and culture isoenzyme analysis, that, even more, detected new infections missed by microscopy. This is in line with another study in rural communities in Nigeria where authors reported the detection of 6 additional cases with immunoassay compared to the diagnosis by microscopy, with a distinction between the pathogenic and non pathogenic species (Babatunde et al., 2016).

Molecular tools allow reconstructing a more reliable picture of the true epidemiology of the disease mainly in endemic area and to better understand the role of the parasite and/or host factors that determine the disease outcome. Of all the different gene targets used to differentiate between E. histolytica and E. dispar by PCR based assays (Sequence of the extra-chromosomal circular rRNA gene, the repetitive sequences in the non coding regions of rDNA, 16S rRNA genes), the small subunit rRNA gene is found to be more sensitive than the best antigen detection method in stool culture (Novati et al., 1996; Mirelman et al., 1997). It is in wide use as it is present in multiple copies on the extra-chromosomal plasmids (Bhattacharya et al., 1988; 1989).

In developed settings, PCR is more used than antigen detection tests due to its higher sensitivity and to the reduced occurrence of cross reactivity with other Entamoeba species (Gutierrez-Cisneros et al., 2010). Blessman et al. (2002) proposed another technique for $E$. histolytica efficiently diagnosis, which is the LightCycler PCR method, found to be fast as it took only $1 \mathrm{~h}$ to proceed 30 samples and specific. However, even if DNA extraction from human feces and PCR performance are not expensive (less than $\$ 7$ per sample), at present, the application of this method is limited to specifically equipped laboratories running the LightCycler.

\subsection{Data on Occurrence}

\subsubsection{Excreta in the environment}

An important incidence of Entamoeba histolytica cysts is present in the environmental samples. In Kano Metropolis, in Nigeria, out of the 100 human fecal samples used as manure, $45 \%$ of them were contaminated by $E$. histolytica/E. dispar, with a mean concentration of 300 cysts/g (Ibrahim, 2008).

\subsubsection{Sewage}

The number and the species of the parasites that could be present in the sewage depend heavily on: (i) the affluent origin reflecting the health of the general population linked and (ii) the season (Fonseca et al., 2016). There are no limitations or guidelines concerning the presence of the protozoa in treated wastewater that will be rejected or reused in agriculture. The WHO guidelines recommend only admissible concentration of helminthes ova. However, it has been demonstrated that there is no relation or correlation between helminthes removal and cysts presence
(Campos, 2008) and that protozoa could be largely prevalent than helminths (Ben Ayed et al., 2009).

E. histolytica is considered, with Cryptosporidium parvum and Giardia duodenalis, as the most common protozoa detected in sewage. The Entamoeba spp. are the third most prevalent pathogens in the raw wastewater and the second in the treated wastewater (Cifuentes et al., 1994; Ben Ayed et al., 2009). Shalaby et al. (2003) and Nahavandi et al. (2015) reported E. histolytica/E. dispar/E. moshkovskii as the most frequent with a prevalence of $29.8 \%$ and $60.9 \%$ respectively in raw Egyptian and Iranian urban wastewater.

Several studies investigated the parasitic occurrence and load in the sewage samples in Tunisia, in North Africa. Alouni et al. (1993) reported a prevalence of Entamoeba histolytica/dispar ranging between 70 and $98 \%$ and between 0 and $15 \%$ respectively in raw and treated wastewater collected from 5 different wastewater treatment plants (WWTPs). These variations were mainly related to the kind of treatment (Activated sludge or lagoon) and to the WWTP location. Later on, Ben Ayed et al. (2009) detected the presence of this complex, by microscopy, in all the raw wastewater samples collected from 17 treatment plants located throughout the country. This figure was corroborated by the work of Jemli et al. (2015) when considering the same treatment plants. Ben Ayed et al. (2009) reported a mean concentration of 893 cysts/L of raw wastewater and 247 cysts/L of treated wastewater with a fraction of 0.28 that passed the treatment. E. histolytica/dispar was present in treated wastewater samples collected from 16 of the 17 WWTPs followed and characterized by 9 different treatment procedures.

Even if the sanitization is better in Tunisia compared to other African countries, lower concentration, ranging between 2 and 55 cysts/L, were detected in raw wastewater samples collected from the International Institute for Water and Environmental Engineering Wastewater treatment plant in the city of Ouagadougou, Burkina Faso (Maiga et al., 2008).

In Dhaka, in Bangladesh, in the twenty samples collected from three different sites in a wastewater treatment plant namely raw, reservoir sample and outlet lagoon, E histolytica/dispar was the most prevalent protozoa identified with respectively $83.33 \%$ in the two first sites and only $8.33 \%$ in the outlet samples, that argue for an important level of elimination (Khanum et al., 2008). Same rate of elimination through wastewater treatment were also reported in the work of Lim et al. (2007) in Malaysia.

In Colombia, an inefficient removal of $E$. histolytica/dispar/moshkovskii was remarked in El Rosa wastewater treatment plant where a prevalence of $80 \%$ of these amoeba presences in treated wastewater was found by microscopy (Fonseca et al., 2016). PCR analysis performed on cultured samples, showed the important overall of only E. moshkovskii, present in all untreated samples and in $78 \%$ of the treated ones. As the PCR was 
performed with cultured samples, the dominance of $E$. moshkovskii, could be attributed to its overgrowth comparing to E. histolytica and E. dispar (Fotedar et al., 2007).

\subsubsection{Sludge}

When following the rate of Entamoeba histolytica/dispar/moskhovskii in the sludge collected from WWTPs of three cities in Saudi Arabia, Malack et al. (2007) noted an important removal with the bed drying process, mainly in the summer time, where the mean concentration of the sludge samples collected in these three cities passed from 46 cysts/g of raw sludge to less than 1 cyst/g of dried sludge.

In Manchinchi and Chaisa cities, in Zambia, the analysis of the sludge samples for Entamoeba histolytica/dispar/moskhovskii presence showed respectively an overall, ranging between 16 and 24 and of 84 cysts/g of biosolids when detected (Phiri et al., 2014).

\subsubsection{Surface water}

Entamoeba histolytica, detected by PCR, was present in two out of six water samples (32\%) collected from the Ankara River in Turkey (Bakir et al., 2003) and two out of eight $(25 \%)$ river water samples in Jakarta, Indonesia (Subahar and Sutanto, 2008). In Thailand, Entamoeba spp. was present in $27 \%$ of the surface and wastewater samples collected (Sukpraset et al., 2008). In Rasht city, in Iran, Entamoeba was present among 4 samples out the 49 collected and in one confirmed water sample of $E$. histolytica by PCR (Hemmati et al., 2015). All these contaminations were attributed to human feces presence, making the surface water inappropriate and unsafe for drinking water.

\subsubsection{Groundwater}

In the 70 wells water samples collected from three sites in Nigeria, the mean of contamination recorded for Entamoeba histolytica/dispar/moskhovskii was ranging between 0,11 and 1,53 cysts/L, corresponding to a prevalence percentage of 38.6\% (Bishop and Inapo, 2015). This occurrence was related to four relevant parameters: effects of well casing, nature of surrounding hygiene, clarity of water and effect of grazing animals around the wells. It was significantly more important in: (i) uncovered wells (43.3\%) than in covered wells (35.0\%), (ii) in unclean surroundings $(48.9 \%)$ than in the clean surroundings (20.0\%), (iii) in turbid well water $(51.9 \%)$ than in relatively clear well water (30.2\%) and (iv) wells frequent by grazing animals (53.1\%).

In Mazandaran, in Iran, only $2.3 \%$ of contamination by Entamoeba histolytica/dispar/moskhovskii was showed in the water samples collected from the wells intended to drinking water (Yousefi et al., 2009).

\subsubsection{Drinking water}

In the southwest part of Iran, Rafiei et al. (2014) analyzed 44 water samples. Among them, twenty eight were positives with a predominance of Entamoeba spp. infection (50\%). These results were positively correlated to local epidemiological reports where Entamoeba spp. was also the most prevalent. This figure is corroborating the findings of Ziaie et al. (2006) in another Iranian district and with those of Ayaz et al. (2011) in Pakistan.

In the region of Hilla in Iraq, Kassim et al. (2015) reported that Entamoeba spp. infection was the highest parasitic contamination of the drinking water samples analyzed with $14.4 \%$, far from the ten other parasites prevalence which were ranging between 0.96 and $1.9 \%$. They also reported differences according to the sampling month and to the town's region. They related this important parasitic contamination to the inefficiency of the sewage system in Iraq, which has directly impacted the drinking water system. Jarallah (2016) corroborated the work of Kassim et al. (2015) and reported that out of the 425 water samples analyzed for parasitic contamination in Iraq, 155 were contaminated with different prevalence according to the site sampling. Among them, Entamoeba histolytica/dispar/moskhovskii was reported the most prevalent parasite present in 34 samples.

\subsubsection{Seawater}

Kheissin and Dmitrieva (1935) study attempted to determine the survival of Entamoeba spp. cysts in seawater. They reported that Entamoeba survival was unaffected by salt concentrations (at salt levels of 20 to 30 $\mathrm{g} / \mathrm{L}$ ) found in seawater. Thus, this can allow the cyst distribution in seawater.

The work of Hilles et al. (2014) discussed the impacts of wastewater discharge into recreational seawater of the Gaza strip. Different levels of contamination were recorded according to the proximity of the sewage discharge points with $E$ histolytica/dispar identified as the most prevalent protozoa (12.5\%).

\subsubsection{Soil}

Among a total of 102 soil samples collected from five local government areas in Nigeria, including refuse dumps, vegetable farms, school play grounds, abattoir, hospital, vicinity of house, gutter and road side, Entamoeba histolytica/dispar was the only protozoa detected in $18.7 \%$ of the soil samples (Ogbolu et al., 2011).

In the sandy beaches of Guanabara in Rio de Janeiro, Bordinhao and Costa (2006) detected E. histolytica/dispar/moschkovskii presence in $16 \%$ of the samples analyzed. The authors attributed this contamination to sewage and to human and animal fecal deposits left in the streets of the city and washed into the drainage channels by the rain. 


\subsubsection{Irrigation water and in crops}

The agriculture wastewater reuse standards and regulations vary worldwide. Some countries allow the reuse of the untreated wastewater like many South American countries (Straus and Bumenthal, 1990), others need at least a secondary treated effluent for the irrigation of specific kind of crops such as Tunisia, South Africa, etc. and others have a very stringent wastewater reuse requirements as only tertiary treated wastewater are allowed like Israel and Saudi Arabia, etc. (Emongor, 2006).

The recovery of parasites in vegetables is a kind of reflection of the overall quality process namely cultivation, irrigation, post-harvest handling and type of water used to wash them. This recovery could also contribute to the determination of the incidence of intestinal parasite in a specific community as they have been demonstrated to be a vehicle for their transmission (Alhabbal, 2015).

Ferrer et al. (2012) conducted an assessment of the diarrhea infection risks associated with wastewater discharge in Bangkok, Thailand. The results showed that Entamoeba histolytica/dispar/moskhovskii and Giardia lamblia were present, at exceeding levels, in both the water and the vegetables irrigated with wastewater-contaminated canal water. This same figure was also reported in Benti and Gemechu (2014) study.

In Costa Rica, depending on crops types, Entamoeba histolytica/dispar/moskhovskii cysts were identified ranging between 2 and $6.2 \%$ of the 80 vegetables samples analyzed. The lowest incidence was noted for several vegetables samples: Carrots, Tomatoes, Cucumbers, etc. A contamination of $2.5 \%(2 / 80)$ and $6.2 \%(5 / 80)$ were reported for Cilantro roots and leaves respectively. For radish and for lettuce, an incidence respectively of 2.5 and 3.8\% were detected (Mong and Arrias, 1996).

The important prevalence of lettuce contamination may be ascribed to (i) its leaves, able to harbor cysts and (ii) to its uneven surfaces facilitating the parasites attachment (Damen, 2007). The level of lettuce contamination was corroborated in the works conducted in two Iranian cities: Shahrekord (Fallah et al., 2012) and Khorrambad (Ezatpour et al., 2013) and in two Egyptian ones: Alexandria (Hassan et al., 2012) and Benha (Eraky et al., 2014).

In Marrakech, in Morocco, collected crops irrigated with raw wastewater were contaminated by $E$. histolytica/dispar/moschovskii. Infection of 10.2; 59; 22 and 21.4 cysts/kg were noted respectively in potatoes, turnip, marrow and squash (Bouhoum and Amahmid, 2002). Authors highlighted the close correlation between the contamination rate and the kind of crops irrigated as those developed on the ground surface were reported with higher contamination level. Authors didn't found a contamination when treated wastewater from waste stabilization ponds was used for crops irrigation.

The results of Erdogrul and Sener (2005) showed that in addition to other parasites, $E$. histolytica/dispar/moschovskii cysts were present in lettuce (8/15 positive samples), parsley (9/20) and strawberry $(12 / 50)$ with an absence in cress samples. Rhallabi et al. (1990) isolated cysts of the pathogenic amoeba in tomatoes with an average of 4 cysts $/ \mathrm{kg}$.

In Khartoum, in Sudan, the most detected parasites in two central markets, was E. histolytica/dispar prevalent in $42.9 \%$ in the exposed vegetable samples (Mohamed et al., 2016) without any signification correlation between this prevalence and the type of vegetable (green onion, tomatoes, Armenian cucumber, beet, watercress, lettuce and carrot). This incidence was in accordance with Tomass and Kidane (2012) in Ethiopia where Entamoeba histolytica/dispar/moskhovskii was the only protozoan parasite detected (18.18\%) besides of these aforementioned vegetables, also in Swiss chard (5/8) and cabbage (1/8) wastewater irrigated. However, this is not in accordance with the work of Tefera et al. (2014) in Southwest Ethiopia, where E. histoyltica/dispar wasn't the most prevalent and was present only in $5.3 \%$ of the total samples of fruits and vegetables analyzed. These authors associated these discrepancies between the two studies conducted in Ethiopia to several factors: (i) the geographical location, (ii) the climatic and environmental conditions, (iii) the kind and the size of samples, (iv) the identification methods and (v) the socio-economic status.

\subsubsection{Fish and in shellfish}

Although that Pazooki and Masoumi (2012) reported the presence of parasitic contamination by two hundred forty seven species in Iranian freshwater fishes captured from different parts of the country, their infection by Entamoeba histolytica wasn't detected.

\subsection{Persistence}

E. histolytica do not reproduce in the environment only in the host. However, the protozoan because of the cyst, characteristics of the wall and the dormancy of the enclosed organism can survive during unfavorable conditions for long periods of time. Mature cysts leave the large intestine with the important trophozoites and they remain viable. These cysts are immediately infective and remain so particularly in moist and cool environments for at least 12 days, but can remain viable (infectious) outside the host for as long as 2 to 4 weeks as summarized in Table 5 . 
Table 5. Environment resistance of E. histolytica/dispar cysts (Freeman, 1979; www.anses.fr; Westcot, 1997)

\begin{tabular}{lcc}
\hline \multicolumn{1}{c}{ Matrix } & Temperature $\mathbf{~}^{\circ} \mathbf{C}$ ) & Persistence (Days) \\
\hline Varied & -10 & 1 \\
Water and sewage sludge & 0 to 4 & 60 to 365 \\
Feces, damp soil, water & 10 to 20 & 10 to 30 \\
Surface or waste water & & $<15$ \\
Cultures & 20 to 30 & $<10$ \\
Septic tank & & 5 to 10 \\
Dry soils / Food & 28 to 34 & 1 to 2 \\
Feces, damp soil, water & 45 & 30 minutes \\
Varied & 50 & 5 minutes \\
\hline
\end{tabular}

In food, the cysts can remain viable for 2 days in temperatures ranges between 20 and $25^{\circ} \mathrm{C}$ (Bonnin et al., 2002). In water or sludge, the cysts are viable for up to 30 days. Nonetheless, they are quickly inactivated by desiccation and extreme temperatures (below $5^{\circ} \mathrm{C}$ or above $40^{\circ} \mathrm{C}$ ). For example on hands, the cysts arre eliminated by desiccation after 10 minutes. Entamoeba histolytica cysts are susceptible to higher temperatures and are quickly eliminated when temperatures reach $45^{\circ} \mathrm{C}$.

The cysts are resistant to gastric acidity. The cysts are resistant to chlorine levels used routinely for water disinfection, during conventional water treatment (Samie et al., 2012).

\subsection{Reductions by sanitation management}

The wastewater treatment processes reduces pathogen numbers in the effluent but also concentrates them in the sludge. Some of these processes are designed specifically to inactivate pathogens and many others do not (Godfree and Farrell, 2005).

The challenge for the physical removal of parasites (oo)cysts in wastewater treatment plants generally is related mainly to their small size (E. histolytica cysts range between 10 and $20 \mu \mathrm{m}$ ) and to their velocity during sedimentation.

\subsection{Excreta and wastewater treatment}

\subsubsection{Onsite sanitation}

3.1.1.1 Dry onsite composting

During composting Day and Shaw (2000) found that a temperature of $55^{\circ} \mathrm{C}$ is sufficient to devitalize E. histolytica cysts in only 1 second while Andreoli et al. (2007) reported that the time required for $E$. histolytica inactivation is $5 \mathrm{~min}$ under a temperature of $50^{\circ} \mathrm{C}$.

3.1.1.2 Water-based onsite sanitation systems

E. histolytica/dispar/moshkovskii was detected varying between 0 and $10^{5}$ cysts $/ 100 \mathrm{ml}$ in a septic tank effluent (McCray et al., 2009). This is corroborated by Lusk et al., 2014 where they concluded that only a small fraction of protozoa cysts could be removed, mainly by physical straining, in a septic tank.

\subsubsection{Waste stabilization ponds (WSP)}

Entamoeba histolytica/dispar/moskhovskii is highly removed with waste stabilization pond with rates reported ranging between $0.89 \log _{10}$ and $>2.0 \log _{10}$ (Klutse and Baleux, 1995) thanks to the coupled actions of the temperature, the sunlight, the $\mathrm{pH}$, the predator microorganisms, the adsorption or trapping into flocs and the most relevant factors, which are the sedimentation and the lengthy retention time.

Bouhoum and Amahmid (2002) proposed the use of this process for the treatment wastewater used for crops irrigation as its outlet was parasite free and containing large amounts of nutrients (Nitrogen and Phosphorus) necessary for plants growth. However, according to Shanthala et al. (2007), protozoan cysts and particularly those of Entamoeba histolytica/dispar/moskhovskii could remain viable in stabilization pond effluents used to irrigate vegetables that are eaten raw.

The efficiency of the WSP is also depending on two main parameters: the number of the maturation ponds and the retention time. To assure a total elimination of the protozoa, Arceivala et al. (1970) proposed a passage by a series of 3 maturation ponds with a 7 day retention time.

A total removal of $E$. histolytica cysts in the final effluent was noted after a consecutive passage by three series of ponds: anaerobic then facultative then maturation ponds. This total removal was also related to the total hydraulic retention time (18 days) (Maiga et al., 2008).

3.1.2.1 Aerated lagoon

Burton and Turner (2003) found between $0.48 \log _{10}$ to $>$ $2.0 \log _{10}$ removal for both Giardia and Entamoeba histolytica/dispar/moskhovskii in plants equipped with an aerated lagoon.

In Ismailia, in Egypt, Shalaby et al. (2003) reported an Entamoeba histolytica/dispar/moskhovskii removal of 0.45 $\log _{10}$ and $0.16 \log _{10}$ respectively with aerated and facultative aerated lagoon. 


\subsubsection{Wetlands}

The wetlands consist of deep ponds with plants that are built on a slant to allow the gravity of the water flow. They are of great relevance and efficiency in wastewater treatment as they do not generate by-products. Rivera et al. (1995) reported a total elimination of Entamoeba histolytica/dispar/moskhovskii in a combined system with gravel and reeds.

3.1.4 Wastewater treatment and resource recovery facilities

The percentage of parasitic removal that will be specific for each kind of wastewater treatment process are, in fact, not a real indication of their destruction but only an indication of their transfer to sludge.

3.1.4.1 Primary treatment

According to the data of the National Research Council (1994), the preliminary treatment has little effect on microorganisms' removal present in the raw wastewater.

\subsection{Sedimentation}

Entamoeba histolytica, removal is about $0.14 \log _{10}$ of its initial load after 1 hour of settling and $0.44 \log _{10}$ after 2 hours (www.unc.edu/courses). Alouini (1998) reported an elimination rate of $0.33 \log _{10}$ after the primary sedimentation in the plant of Charguia, in Tunisia. Awuah et al. (2006) reported almost this same removal rate of Entamoeba histolytica/dispar/moskhovskii.

\subsection{Enhanced primary-coagulation}

Jiménez et al. (2001) reported that the advanced primary treatment could remove between $0.3 \log _{10}$ to $0.69 \log _{10}$ of the protozoan cysts overall including Entamoeba histolytica/dispar/moskhovskii.

\subsubsection{Trickling filters}

The E. histolytica reduction through this process, as followed by Panicker and Krishnammorthi (1978) and Feachem et al. (1983), was reported respectively to be 0.76 $\log _{10}$ and between $0.53 \log _{10}$ and $1.22 \log _{10}$.

3.1.4.3 Activated sludge

Vaz da Costa Vagas et al. (1996) reported that biological treatment, such as the activated sludge or oxidation ditches, although more efficient in parasites removal, they do not produce a parasite free effluent like the effluent obtained by lagoon.

A lower rate of E. histolytica/dispar/moshkovskii removal was reported $0.37 \log _{10}$ in Tonani et al. (2011) one year work at a WWTP in Sao Paulo, in Brazil. In Iran, Yousefi and Hezarjaribi (2013) found that activated sludge, in a hospital WWTP, coupled with extended aeration presented the lowest rate of $E$. histolytica/dispar/moshkovskii cysts removal.

A recapitulation of the effectiveness of all these cited wastewater treatment processes and the generated sludge are reported on Table 6.

Table 6. Summary of the Entamoeba spp. removal efficiencies of various sewage treatment processes (Awuah, 2006)

\begin{tabular}{|c|c|c|c|c|c|c|}
\hline Parameters & $\begin{array}{c}\text { Primary } \\
\text { sedimentation }\end{array}$ & $\begin{array}{c}\text { Trickling } \\
\text { filter with } \\
\text { sludge } \\
\text { digetion } \\
\text { and drying }\end{array}$ & $\begin{array}{l}\text { Activated sludge } \\
\text { with primary and } \\
\text { secondary } \\
\text { sedimentation, } \\
\text { digestion and } \\
\text { sludge drying }\end{array}$ & $\begin{array}{l}\text { Oxidation ditch } \\
\text { with } \\
\text { sedimentation } \\
\text { and sludge } \\
\text { drying }\end{array}$ & $\begin{array}{c}\text { Waste } \\
\text { stabilization } \\
\text { ponds with } \\
\text { minimum } \\
\text { retention time }= \\
25 \text { days }\end{array}$ & Septic tanks \\
\hline $\begin{array}{l}\log _{10} \\
\text { removal }\end{array}$ & 0.05 to 0.3 & 0.3 & 0.3 & 0.3 & $>2 \log _{10}$ & 0 \\
\hline $\begin{array}{l}\text { Final } \\
\text { sludge }\end{array}$ & Contaminated & Safe & Safe & Safe & Not applicable & Contaminated \\
\hline
\end{tabular}

\subsubsection{Oxidation ditch}

Sobsey (www.unc.edu/courses) reported a $1.05 \log _{10}$ removal of $E$. histolytica with oxidation ditch process followed by sedimentation.

3.1.4.5 Membrane bioreactors/USAB

For the enhancement of primary sewage treatment, large scale high rate anaerobic reactors were used, including Upflow Anaerobic Sludge Blanket (USAB). According to Chong et al. (2012), amoeba cysts should be removed but no data were available using a USAB-septic tank technology with an anaerobic system.

3.1.4.6 Anaerobic/anoxic digestion and biogas

Anaerobic or anoxic digestion is closely related to the digestion time and to the system temperature (Mesophilic or thermophilic).

Anaerobic membrane bioreactors (MBR) are a great potential-application to achieve two principal objectives: the energy recovery and a better effluent quality for reuse. 
In a study accomplished in Sfax Biotechnology Center (CBS) in Tunisia, the results obtained by Saddoud et al. (2007) indicated that the anaerobic MBR allowed an effective and total removal of $>2.0 \log _{10}$ of protozoan cysts.

In Brazil, Benatti et al. (2002), showed that the sewage sludge samples obtained after being putted without previous thickening in a digester for 20 days, were free of Entamoeba spp. in spite of the important load contamination of the affluent. However, in Kathmandu, E. histolytica/dispar/moshkovskii was detected in the sewage sludge samples collected from an anaerobic digesters working respectively at 10 to $20{ }^{\circ} \mathrm{C}$ for 30 days and at mesophilic temperature $\left(35 \pm 2{ }^{\circ} \mathrm{C}\right.$ ) for 25 days (Poudel et al., 2010).

According to Tawfik et al. (2015), the treatment of domestic wastewater in a pilot scale up flow anaerobic hybrid $(\mathrm{AH})$ reactor $\left(0.9 \mathrm{~m}^{3}\right)$ in combination with down flow hanging sponge (DHS) system $\left(1.3 \mathrm{~m}^{3}\right)$ was investigated. This combined system, operated at a hydraulic retention time (HRT) of $6 \mathrm{~h}$ for the $\mathrm{AH}$ and $3.2 \mathrm{~h}$ for the DHS system, was very efficient for the removal of the Entamoeba cysts. 3.1.4.7 Coagulation

This process has been used as the main treatment process in order to assure the production of a treated wastewater suitable for agricultural reuse at a reasonable cost (Jiménez et al., 2001). For the coagulation stage, as protozoa (oo)cysts are naturally electronegative (CapizziBanas et al., 2002), precipitate enmeshment using metal hydroxides can assure their reduction to more than $2.0 \log _{10}$ (Gray, 1999; Bouzid et al., 2008).

3.1.4.8 Filtration

Rapid filtration eliminates $1.0 \log _{10}$ of Entamoeba species with a filtration rate less than 2.4 meter/h. The addition of a coagulant could increase this removal rate to $2.0 \log _{10}$ (Leong, 1983; Jimenez et al., 2001; Bitton, 2005).

Jimenez et al. (2001) highlighted the relevance of the integration of this procedure in wastewater treatment by comparing the protozoa overall (Giardia, Entamoeba coli and E. histolytica/dispar/moshkovskii) in three samples namely raw wastewater, after an advanced primary treatment (APT) and after APT followed by filtration. Authors reported protozoa prevalence ranging between respectively: 1007 to $1814 ; 400$ to 524 and 190 to 524 cysts/L.

3.1.4.9 Membranes (Micro, ultra, reverse osmosis and membrane bioreactors)

Protozoan (oo)cysts and more specifically E. histolytica, that the size is ranging from 3 to $20 \mu \mathrm{m}$, could easily be retained as they are larger than the pore size of an microfiltration $(0.1-10 \mu \mathrm{m})$ or ultrafiltration (5 to $100 \mathrm{~nm}$ ) membranes and a total removal of protozoa could be expected (Ottoson et al., 2006; Bitton, 2010).

According to Fletcher et al. (2012); although that several emerging methods for wastewater treatment involving membrane and filtration technologies namely pressure-driven membrane processes such as microfiltration, ultrafiltration, nanofiltration and reverse osmosis are now extensively used, their application in wastewater is still limited due to the inorganic fouling.

Coagulation-floculation separation, sand filtration and membrane treatments through micro or ultra-filtration allow the reduction of $3.0 \log _{10}$ to $4.0 \log _{10}$ of $E$. histolytica/dispar/moshkovskii quadric nucleated cysts from the initial load. This is obtained when the turbidity of filtered water is at most 0.5 or even $0.3 \mathrm{NFU}$ (https://www.anses.fr).

Lauer (1991) described a demonstration plant built with a debit of $44 \mathrm{l} / \mathrm{s}$, assessed to examine the feasibility of converting secondary treated wastewater to potable water in Denver, USA. This pilot project, designed with an excessive level of protection, was composed of coagulation-flocculation with lime, recarbonation, filtration, selective ion exchange, carbon adsorption first step, ozonation, carbon adsorption second step, reverse osmosis and disinfection with chlorine dioxide. The effluents generated, with reverse osmosis and ultrafiltration, were under the detection limits for the presence of Entamoeba histolytica (Lauer and Rogers, 1994).

3.1.4.10 Biosolids management (Sludge, fecal sludge management)

Phiri et al. (2014) consider the biosolids drying beds as an effective way of sludge treatment and reuse but at least for a period of 5 weeks even if an important inactivation was noted since the second week. They also highlighted the importance of the Gamma rays radiations ( $\mathrm{kGy}$ ) as they obtained sludge samples free Entamoeba histolytica even after lower doses (5 kGy).

\subsection{Disinfection}

Disinfection is the process used for microorganisms control and elimination. Its efficiency depends mainly on the disinfecting agent (Chlorine, ozone and Ultraviolet), the type and variety of microorganisms, the dosage, the exposure time and the water composition.

Schafer et al. (2004) reported a wall resistance of (oo)cysts to disinfection.

\subsubsection{Chemical disinfection (Chlorine, ozone)}

Hijnen (2008) and EPA's Water Treatment Manual Disinfection (2011) described E. histolytica cysts as resistant against the commonly used concentrations of the chemical disinfectants: chlorine and ozone.

Chlorine, as a widely used disinfectant at water treatment plants, could not inactivate some protozoa cysts if its density and contact time with water are reduced (Liberti et al., 2003). Protozoa cysts, including E. histolytica, have shown resistance to low doses of chlorine (Pulido, 2005). Shalaby et al. (2003) stated that E. histolytica cysts elimination by chlorination was closely related to the chlorine dose, to the contact time and to the affluent concentration in pathogenic amoeba. In fact, as reported in Table 7, a contact time of $120 \mathrm{mg} \cdot \mathrm{min} / \mathrm{L}$ at an 
alkaline $\mathrm{pH}$, will inactivate $2.0 \log _{10}(99 \%)$ of $E$. histolytica/E.dispar cysts.

Table 7. Disinfectants effects on E. histolytica/E. dispar cysts (www.anses.fr)

\begin{tabular}{|c|c|c|c|}
\hline Product & Conditions & Concentration (mg/l) or CT* (mg.min/L) & $\begin{array}{c}\text { Cyst inactivation } \\
\left(\log _{10} \text { Reductions) }\right.\end{array}$ \\
\hline Active chlorine & Aqueous solution & $\begin{array}{c}20 \mathrm{mg} \cdot \mathrm{min} / \mathrm{L}\left(30^{\circ} \mathrm{C} \mathrm{pH} \mathrm{7)}\right. \\
120 \mathrm{mg} \cdot \mathrm{min} / \mathrm{L}(\mathrm{pH} 10)\end{array}$ & 2 \\
\hline Ozone & & 0.7 to $1.1 \mathrm{mg} / \mathrm{l}$ & $>1.7$ \\
\hline Bromine & Solution & $\begin{array}{c}35 \mathrm{mg} \cdot \mathrm{min} / \mathrm{L}\left(\mathrm{pH} 4 \text { at } 30^{\circ} \mathrm{C}\right) \\
40 \mathrm{mg} \cdot \mathrm{min} / \mathrm{L}(\mathrm{pH} 10)\end{array}$ & 3 \\
\hline
\end{tabular}

Jimenez et al. (2001) followed the effect of chlorine on three protozoa (Giardia, E. coli and E. histolytica) elimination and reported removal and inactivation assured by this process where their prevalence (cysts/L) ranged between 1007 and 1814 in raw wastewater and between 1 and 30 after chlorination.

Table 7 resume the effects of the chemical disinfectants on the removal of E. histolytica/E. dispar cysts.

\subsubsection{Physical disinfection (Ultraviolet):}

In order to ensure continuous supplies of healthy water worldwide from waterborne protozoa parasites and for the monitoring of drinking water, results obtained from studies of bath solar disinfection (SODIS) with combined effect of temperature and UV radiation, are so far encouraging with cysts including E. histolytica rendered completely noninfective after exposures to up to 10 hours at $40^{\circ} \mathrm{C}$. 


\section{References}

Al-Braiken, F.A. (2008). Is intestinal parasitic infection still a public health concern among Saudi children?. Saudi Medical Journal. 29, pp. 1630-1635.

Alhabbal, A. (2015). The prevalence of parasitic contamination on common cold vegetables in Alqalamoun Region. International Journal of Pharmaceutical Sciences Review and Research. 30, pp. 94-97.

Ali, I.K.M., Hossain, M.B., Roy, S., Ayeh-Kumi, P.F., Petri, W.A., Haque, R. et al. (2003). Entamoeba moshkovskii infections in children in Bangladesh. Emerging Infectious Diseases. 9, pp. 580-584.

Ali, I.K.M., Solaymani-Mohammadi, S., Akhter, J., Roy, S., Gorrini, C., Calderaro, A. et al. (2008). Tissue Invasion by Entamoeba histolytica: Evidence of Genetic Selection and/or DNA Reorganization Events in Organ Tropism. PLoS Neglected Tropical Diseases.

Alouini, Z. (1998). Devenir des øeufs et kystes de parasites au cours d'un cycle d'épuration de la station Cherguia à Tunis. La Houille Blanche. 7, pp. 60-64.

Alouni, Z. (1993). Flux de la charge parasitaire dans cinq stations d'épuration en Tunisie. Revue des sciences de leau. 6, pp. 453.

Amuta, E., Olusi, T. and Houmsou, R. (2008). Relationship of intestinal parasitic infections and malnutrition among school children in Makurdi, Benue State - Nigeria. The Internet Journal of Epidemiology. 7, pp. 1-6.

Anaya-Velazquez, F. and Padilla-Vaca, F. (2011). Virulence of Entamoeba histolytica: a challenge for human health research. Future Microbiology. 6, pp. 255-258.

Andersson, Y. and De Jong, B. (1989). An outbreak of giardiasis and amoebiasis at a ski resort in Sweden. Water Science and Technology. 21, pp. 143-146.

Andreoli, C.V., von Sperling, M., Fernandes, F. and Ronteltap, M. (2007). Sludge treatment and disposal. IWA publishing.

Anuar, T.S., Al-Mekhlafi, H.M., Ghani, M.K.A., Osman, E., Yasin, A.M., Nordin, A. et al. (2012). Prevalence and Risk Factors Associated with Entamoeba histolytica/dispar/moshkovskii Infection among Three Orang Asli Ethnic Groups in Malaysia. PLoS One.

Aristizabal, H., Acevedo, J. and Botero, M. (1991). Fulminant amebic colitis. World Journal of Surgery. 15, pp. $216-221$.

Awuah, E. (2006). Pathogen Removal Mechanisms in Macrophyte and Algal Waste Stabilization Ponds, The Netherlands.

Ayaz, S., Khan, S., Khan, S.N., Bibi, F., Shamas, S. and Akhtar, M. (2011). Prevalence of zoonotic parasites in drinking water of three districts of Khyber Pakhtunkhwa Province, Pakistan. Pakistan Journal of Life and Social Sciences. 9, pp. 67-69.

Babatunde, S., Ajiboye, E., Adedayo, R. and Adetumbi, M. (2016). Immunoassay Method as Diagnostic Tool for Enteric Amoebiasis and Cryptosporidiosis in Some Rural Communities, of Kwara State, Nigeria.

Bakir, B., Tanyuksel, M., Saylam, F., Tanriverdi, S., Araz, R.E., Hacim, A.K. et al. (2003). Investigation of waterborne parasites in drinking water sources of Ankara, Turkey. Journal of Microbiology. 41, pp. 148-151.

Barwick, R.S., Uzicanin, A., Lareau, S., Malakmadze, N., Imnadze, P., Iosava, M. et al. (2002). Outbreak of amebiasis in Tbilisi, Republic of Georgia, 1998. American Journal of Tropical Medicine and Hygiene. 67, pp. 623-631.

Beck, D.L., Dogan, N., Maro, V., Sam, N.E., Shao, J. and Houpt, E.R. (2008). High prevalence of Entamoeba moshkovskii in a Tanzanian HIV population. Acta Tropica. 107, pp. 48-49. 
Benatti, C.T., Tavares, C.R.G., Dias, B.P. and Moitinho, M.D.R. (2002). Operation of a slow rate anaerobic digester treating municipal secondary sludge. Electronic Journal of Biotechnology. 5, pp. 216-227.

Ben Ayed, L., Schijven, J., Alouini, Z., Jemli, M. and Sabbahi, S. (2009). Presence of parasitic protozoa and helminth in sewage and efficiency of sewage treatment in Tunisia. Parasitology Research. 105, pp. 393-406.

Ben Ayed, S., Aoun, K., Maamouri, N., Ben Abdallah, R. and Bouratbine, A. (2008). Short Report: First Molecular Identification of Entamoeba moshkovskii in Human Stool Samples in Tunisia. American Journal of Tropical Medicine and Hygiene. 79, pp. 706-707.

Ben Ayed, S., Ben, A.R., Mousli, M., Aoun, K., Thellier, M. and Bouratbine, A. (2008). Molecular differentiation of Entamoeba histolytica and Entamoeba dispar from Tunisian food handlers with amoeba infection initially diagnosed by microscopy. Parasite. 15, pp. 65-68.

Benetton, M.L., Goncalves, A.V., Meneghini, M.E., Silva, E.F. and Carneiro, M. (2005). Risk factors for infection by the Entamoeba histolytica/E. dispar complex: an epidemiological study conducted in outpatient clinics in the city of Manaus, Amazon Region, Brazil. Transactions of the Royal Society of Tropical Medicine and Hygiene. 99, pp. 532-540.

Benti, G. and Gemechu, F. (2014). Parasitic contamination on vegetables irrigated with Awash river in selected farms, eastern Showa, Ethiopia. Journal of Parasitology and Vector Biology. 6, pp. 104-110.

Bhattacharya, S., Bhattacharya, A. and Diamond, L.S. (1988). Comparison of repeated DNA from strains of Entamoeba histolytica and other Entamoeba. Molecular and Biochemical Parasitology. 27, pp. 257-262.

Bhattacharya, S., Bhattacharya, A., Diamond, L.S. and Soldo, A.T. (1989). Circular DNA of Entamoeba histolytica encodes ribosomal RNA. Journal of Protozoology. 36, pp. 455-458.

Bishop, H.G. and Inabo, H.I. (2015). Incidence of Entamoeba Histolytica in Well Water in Samaru-Zaria, Nigeria. International Journal of Scientific Research in Environmental Sciences. 3, pp. 16.

Bitton, G. (2010). Microbial Source Tracking. Wastewater Microbiology. Fourth ed. pp. 197-215.

Bitton, G. (2005). Wastewater Microbiology. Third ed. John Wiley and Sons, Inc. Hoboken, New Jersey.

Blessmann, J., Le Van, A. and Tannich, E. (2006). Epidemiology and treatment of amebiasis in Hue, Vietnam. Archives of Medical Research. 37, pp. 270-272.

Blessmann, J., Van, L.P., Nu, P.A.T., Thi, H.D., Muller-Myhsok, B., Buss, H. et al. (2002). Epidemiology of amebiasis in a region of high incidence of amebic liver abscess in central Vietnam. American Journal of Tropical Medicine and Hygiene. 66, pp. 578-583.

Bonnin, A. and E Cas, D. (2002). Fiche AFSSA Entamoeba histolytica/dispar.

Bordinhão, P. and Costa, L. (2006). Areia contaminada das praias da Guanabara Contaminated sand of the beaches of Guanabara. Bol Comissão Meio Ambiente Assembléia Legislativa Est Rio de Janeiro. pp. 1.

Bouali, S., Ben Said, I., Bouhoula, A., Boubaker, A., Nidhameddine, K., Kallel, H. et al. (2014). Amoebic cerebral abscess : a report of three cases with literature review. African Journal of Neurological Sciences. 33, pp. 3-9.

Bouhoum, K. and Amahmid, O. (2002). Municipal wastewater reuse for irrigation: Productivity and contamination level of irrigated crops by pathogens. Proceedings of International Symposium on Environmental Pollution Control and Waste Management. pp. 582-587.

Bouratbine, A., Maamouri, N., Ben Abdallah, R.R., Aoun, K., Haouet, S., Boubaker, J. et al. (2003). Epidemiological, clinical and parasitological data concerning intestinal amebiasis in northern Tunisia. La Tunisie Médicale. 81, pp. 318-322.

Bouzid, M., Steverding, D. and Tyler, K.M. (2008). Detection and surveillance of waterborne protozoan parasites. Current opinion in biotechnology. 19, pp. 302-306. 
Bray, R.S. and Harris, W.G. (1977). The epidemiology of infection with Entamoeba histolytica in the Gambia, West Africa. Transactions of the Royal Society of Tropical Medicine and Hygiene. 71, pp. 401-407.

Bruchhaus, I., Jacobs, T., Leippe, M. and Tannich, E. (1996). Entamoeba histolytica and Entamoeba dispar: differences in numbers and expression of cysteine proteinase genes. Molecular Microbiology. 22, pp. 255-263.

Brumpt, E. (1925). Étude sommaire de l'Entamoeba dispar n. sp. Amibe à kystes quadrinucléés, parasite de l'homme. Bulletin de L'Académie Nationale de Médecine. 94, pp. 943-952.

Bumb, R.A. and Mehta, R.D. (2006). Amoebiasis cutis in HIV positive patient. Indian Journal of Dermatology, Venereology and Leprology. 72, pp. 224-226.

Burton, C.H. and Turner, C. (2003). Manure management: Treatment strategies for sustainable agriculture, Editions Quae.

Capizzi-Banas, S., Maux, M. and Schwartzbrod, J. (2002). Surface hydrophobicity of Ascaris eggs and Giardia cysts. Helminthologia. 39, pp. 197-204.

Chaker, E., S Hadj, B., Khaled, S., Ben Moussa, M. and Ben Rachid, M.S. (1995). Digestive parasitic diseases. A continuous current problem. Tunis Med. 73, pp. 53-56.

Chen, K.T., Chen, C.J. and Chiu, J.P. (2001). A school waterborne outbreak involving both Shigella sonnei and Entamoeba histolytica. Journal of Environmental Health. 64, pp. 9-13,26.

Cho, J. and Eichinger, D. (1998). Crithidia fasciculata induces encystation of Entamoeba invadens in a galactose-dependent manner. Journal of Parasitology. 84, pp. 705-710.

Chong, S., Sen, T.K., Kayaalp, A. and Ang, H.M. (2012). The performance enhancements of upflow anaerobic sludge blanket (UASB) reactors for domestic sludge treatment-a state-of-the-art review. Water Research. 46, pp. 3434-3470.

Cifuentes, E., Blumenthal, U., Ruiz-Palacios, G., Bennett, S. and Peasey, A. (1994). Epidemiologic setting of the agricultural use of sewage: Valle del Mezquital, Mexico. Salud Pública de México. 36, pp. 3-9.

Damen, J.G., Banwat, E.B., Egah, D.Z. and Allanana, J.A. (2007). Parasitic contamination of vegetables in Jos, Nigeria. Annals of African Medicine. 6, pp. 115-118.

Dawson, D. (2005). Foodborne protozoan parasites. International journal of food microbiology. 103, pp. 207-227.

Day, M. and Shaw, K. (2001). Biological, chemical and physical processes of composting. Compost Utilization in Horticultural Cropping Systems. Lewis Publishers. Boca Raton, FL. pp. 17-50.

de Lalla, F., Rinaldi, E., Santoro, D., Nicolin, R. and Tramarin, A. (1992). Outbreak of Entamoeba histolytica and Giardia lamblia infections in travellers returning from the tropics. Infection. 20, pp. 78-82.

Diamond, L.S. and Clark, C.G. (1993). A redescription of Entamoeba histolytica Schaudinn, 1903 (Emended Walker, 1911) separating it from Entamoeba dispar Brumpt, 1925. Journal of Eukaryotic Microbiology. 40, pp. 340-344.

Duc, P.P., Nguyen-Viet, H., Hattendorf, J., Zinsstag, J., Cam, P.D. and Odermatt, P. (2011). Risk factors for Entamoeba histolytica infection in an agricultural community in Hanam province, Vietnam. Parasites and Vectors. pp. 4.

Eichinger, D. (2001). A role for a galactose lectin and its ligands during encystment of Entamoeba. Journal of Eukaryotic Microbiology. 48, pp. 17-21.

Ejaz, M., Murtaza, G., Ahmad, M., Khan, S.A., Najam-us-Saqib, Q., Bin Asad, M.H.H. et al. (2011). Determination of the prevalence of Entamoeba histolytica in human ata private fertilizer company hospital in Pakistan using microscopic technique. African Journal of Microbiology Research. 5, pp. 149-152.

El-Sheikh, S.M. and El-Assouli, S.M. (2001). Prevalence of viral, bacterial and parasitic enteropathogens among young children with acute Diarrhoea in Jeddah, Saudi Arabia. Journal of Health Population and Nutrition. 19, pp. 25-30. 
Emongor, V.E. (2006). Use of Secondary Effluent in Food Production in Botswana. Journal of Applied Sciences. 6, pp. 38-324.

EPA (2011). Water treatment manual: Disinfection. Office of Environmental Enforcement - EPA. Ireland.

Eraky, M.A., Rashed, S.M., Nasr Mel, S., El-Hamshary, A.M. and A El-Ghannam, S. (2014). Parasitic contamination of commonly consumed fresh leafy vegetables in benha, Egypt. Journal of Parasitology Research. pp. 613960.

Erdogrul, O. and Sener, H. (2005). The contamination of various fruit and vegetable with Enterobius vermicularis, Ascaris eggs, Entamoeba histolyca cysts and Giardia cysts. Food Control. 16, pp. 559-562.

Europe, U.Nations Ec (Submitted). Environmental performances reviews, Georgia.

Ezatpour, B., Chegeni, A.S., Abdollahpour, F., Aazami, M. and Alirezaei, M. (2013). Prevalence of parasitic contamination of raw vegetables in Khorramabad, Iran. Food Control. 34, pp. 92-95.

Fallah, A.A., Pirali-Kheirabadi, K., Shirvani, F. and Saei-Dehkordi, S.S. (2012). Prevalence of parasitic contamination in vegetables used for raw consumption in Shahrekord, Iran: Influence of season and washing procedure. Food Control. 25, pp. 617-620.

Fathallah, A., Saghrouni, F., Madani, B., Ben Rejeb, N. and Ben Said, M. (2004). Digestive parasitism in Sousse area. Results of a 16 years retrospective study. La Tunisie Médicale. 82, pp. 335-343.

Feachem, R., Mara, D.D. and Bradley, D.J. (1983). Sanitation and disease. John Wiley and Sons. Washington DC.

Ferrer, A., Nguyen-Viet, H. and Zinsstag, J. (2012). Quantification of diarrhea risk related to wastewater contact in Thailand. Ecohealth. 9, pp. 49-59.

Filho, PC.Campos, Barros, L.M., Campos, J.O., Braga, V.B., Cazorla, I.M., Albuquerque, G.R. et al. (2008). Zoonotic parasites in dog feces at public squares in the municipality of Itabuna, Bahia, Brazil. Revista Brasileira de Parasitologia Veterinária. 17, pp. 206-209.

Fletcher, S.M., Stark, D., Harkness, J. and Ellis, J. (2012). Enteric protozoa in the developed world: a public health perspective. Clinical Microbiology Reviews. 25, pp. 420-449.

Flores, B.M., Stanley, Jr, S.L., Yong, T.S., Ali, M., Yang, W., Diedrich, D.L. et al. (1996). Surface localization, regulation, and biologic properties of the 96-kDa alcohol/aldehyde dehydrogenase (EhADH2) of pathogenic Entamoeba histolytica. The Journal of Infectious Diseases. 173, pp. 226-231.

Florez, A.C., Garcia, D.A., Moncada, L. and Beltran, M. (2003). Prevalence of microsporidia and other intestinal parasites in patients with HIV infection, Bogota, 2001. Biomedica. 23, pp. 274-282.

Fonseca, J.A., Heredia, R.D., Ortiz, C., Mazo, M., Clavijo-Ramirez, C.A. and Lopez, M.C. (2016). Identification of Entamoeba moshkovskii in Treated Waste Water Used for Agriculture. Ecohealth. 13, pp. 156-160.

Fotedar, R., Stark, D., Beebe, N., Marriott, D., Ellis, J. and Harkness, J. (2007). Laboratory diagnostic techniques for Entamoeba species. Clinical Microbiology Reviews. 20, pp. 511-532.

Fotedar, R., Stark, D., Marriott, D., Ellis, J. and Harkness, J. (2008). Entamoeba moshkovskii infections in Sydney, Australia. European Journal of Clinical Microbiology and Infectious Diseases. 27, pp. 133-137.

Freedman, D.O., Weld, L.H., Kozarsky, P.E., Fisk, T., Robins, R., von Sonnenburg, F. et al. (2006). Spectrum of disease and relation to place of exposure among ill returned travelers. The New England Journal of Medicine. 354, pp. 119-130.

Freeman, B.A. (1979). Burrows textbook of microbiology. 21st ed. Saunders WB Co. Philadelphia, PA.

Gatti, S., Swierczynski, G., Robinson, F., Anselmi, M., Corrales, J., Moreira, J. et al. (2002). Amebic infections due to the Entamoeba histolytica-Entamoeba dispar complex: a study of the incidence in a remote rural area of Ecuador. The 
American Journal of Tropical Medicine and Hygiene. 67, pp. 123-127.

Ghasemi, E., Rahdar, M. and Rostami, M. (2015). Prevalence of Entamoeba histolytica/dispar in drinking water in the city of Shush, Khuzestan Province in 2011. International Journal of Current Microbiology and Applied Sciences. 4, pp. 582-588.

Gill, G. and Beeding, N. (2004). Tropical Medicine. 6th ed. Wiley Blackwell. Oxford, UK.

Godfree, A. and Farrell, J. (2005). Processes for managing pathogens. Journal of Environmental Quality. 34, pp. $105-113$.

Gonzales, M.L., Dans, L.F. and Martinez, E.G. (2009). Antiamoebic drugs for treating amoebic colitis. Cochrane database of systematic reviews. 2, pp. CD006085.

Gonzalez-Ruiz, A., Haque, R., Rehman, T., Aguirre, A., Hall, A., Guhl, F. et al. (1994). Diagnosis of amebic dysentery by detection of Entamoeba histolytica fecal antigen by an invasive strain-specific, monoclonal antibody-based enzyme-linked immunosorbent assay. Journal of Clinical Microbiology. 32, pp. 964-970.

Gottke, M.U., Keller, K., Belley, A., Garcia, R.M., Hollingsworth, M.A., Mack, D.R. et al. (1998). Functional heterogeneity of colonic adenocarcinoma mucins for inhibition of Entamoeba histolytica adherence to target cells. Journal of Eukaryotic Microbiology. 45, pp. 17S-23S.

Gray, N.F. (1999). Water Technology: An introduction for Environmental Scientists and Engineers. Arnold Publisher. London.

Gunther, J., Shafir, S., Bristow, B. and Sorvillo, F. (2011). Amebiasis-related mortality among United States residents, 1990-2007. The American Journal of Tropical Medicine and Hygiene. 85, pp. 1038-1040.

Gutierrez-Cisneros, M.J., Cogollos, R., Lopez-Velez, R., Martin-Rabadan, P., Martinez-Ruiz, R., Subirats, M. et al. (2010). Application of real-time PCR for the differentiation of Entamoeba histolytica and E. dispar in cyst-positive faecal samples from 130 immigrants living in Spain. Annals of Tropical Medicine and Parasitology. 104, pp. 145-149.

Hailemariam, G., Kassu, A., Abebe, G., Abate, E., Damte, D., Mekonnen, E. et al. (2004). Intestinal parasitic infections in HIV/AIDS and HIV seronegative individuals in a teaching hospital, Ethiopia. Japanese Journal of Infectious Diseases. 57, pp. 41-43.

Hamano, S., Becker, S., Asgharpour, A., Ocasio, Y.P., Stroup, S.E., McDuffie, M. et al. (2008). Gender and genetic control of resistance to intestinal amebiasis in inbred mice. Genes and Immunity. 9, pp. 452-461.

Hamit, M., Tidjani, M. and Bilong, C.B. (2008). Recent data on the prevalence of intestinal parasites in N'Djamena, Chad Republic. African Journal of Environmental Science and Technology. 2, pp. 407-411.

Haque, R., Faruque, A.S., Hahn, P., Lyerly, D.M. and Petri, Jr, W.A. (1997). Entamoeba histolytica and Entamoeba dispar infection in children in Bangladesh. The Journal of Infectious Diseases. 175, pp. 734-736.

Haque, R., Huston, C.D., Hughes, M., Houpt, E. and Petri, Jr, W.A. (2003). Amebiasis. The New England Journal of Medicine. 348, pp. 1565-1573.

Haque, R., Mollah, N.U., Ali, I.K., Alam, K., Eubanks, A., Lyerly, D. et al. (2000). Diagnosis of amebic liver abscess and intestinal infection with the TechLab Entamoeba histolytica II antigen detection and antibody tests. Journal of Clinical Microbiology. 38, pp. 3235-3239.

Haque, R., Mondal, D., Duggal, P., Kabir, M., Roy, S., Farr, B.M. et al. (2006). Entamoeba histolytica infection in children and protection from subsequent amebiasis. Infection and Immunity. 74, pp. 904-909.

Harthi, SA.Al and Jamjoom, M.B. (2007). Diagnosis and Differentiation of Entamoeba Infection in Makkah Al Mukarramah Using Microscopy and Stool Antigen Detection Kits. World Journal of Medical Sciences. 2, pp. 15-20.

Hassan, A., Farouk, H. and Abdul-Ghani, R. (2012). Parasitological contamination of freshly eaten vegetables collected from local markets in Alexandria, Egypt: A preliminary study. Food Control. 26, pp. 500-503. 
Hatam-Nahavandi, K., Mahvi, A.H., Mohebali, M., Keshavarz, H., Mobed, I. and Rezaeian, M. (2015). Detection of parasitic particles in domestic and urban wastewaters and assessment of removal efficiency of treatment plants in Tehran, Iran. Journal of Environmental Health Science and Engineering.

Heckendorn, F., N'Goran, E.K., Felger, I., Vounatsou, P., Yapi, A., Oettli, A. et al. (2002). Species-specific field testing of Entamoeba spp. in an area of high endemicity. Transactions of the Royal Society of Tropical Medicine and Hygiene. 96, pp. 521-528.

Hegazi, M.A., Patel, T.A. and El-Deek, B.S. (2013). Prevalence and characters of Entamoeba histolytica infection in Saudi infants and children admitted with diarrhea at 2 main hospitals at south Jeddah: a re-emerging serious infection with unusual presentation. Brazilian Journal of Infectious Diseases. 17, pp. 32-40.

Hemmati, A., Hooshmand, E. and Hosseini, M.J. (2015). Identification of Entamoeba histolytica by Molecular Method in Surface Water of Rasht City, Iran. Iranian Journal of Public Health. 44, pp. 238-243.

Heredia, R.D., Fonseca, J.A. and Lopez, M.C. (2012). Entamoeba moshkovskii perspectives of a new agent to be considered in the diagnosis of amebiasis. Acta Tropica. 123, pp. 139-145.

Heymann, D.L. (2008). Control of communicable diseases manual. American Public Health Association.

Hijnen, W.A.M. (2008). Elimination of microorganisms in water treatment. University Utrecht. Netherlands.

Hilles, A.H., Hindi, AI.Al and Safieh, YA.Abu (2014). Assessment of parasitic pollution in the coastal seawater of Gaza city. Journal of Environmental Health Science and Engineering. 12, pp. 26.

Hung, C.C., Ji, D.D., Sun, H.Y., Lee, Y.T., Hsu, S.Y., Chang, S.Y. et al. (2008). Increased Risk for Entamoeba histolytica Infection and Invasive Amebiasis in HIV Seropositive Men Who Have Sex with Men in Taiwan. PLoS Neglected Tropical Diseases.

Huston, C.D. and Petri, Jr, W.A. (1999). Amebiasis: Clinical Implications of the Recognition of Entamoeba dispar. Current infectious disease reports. 1, pp. 441-447.

Ibrahim, S. (2008). Transmission of Amoebiasis at some selected areas of Kano Metropolis, Kano State, Nigeria : The role of human faeces used as manure. Bayero Journal of Pure and Applied Sciences. 1, pp. 32-35.

Jackson, T.F.G.H. and Ravdin, J.I. (2000). Epidemiology of amebiasis. Amebiasis. Imperial College Press. London, UK.

Jackson, T.F.H.G. (1998). Entamoeba histolytica and Entamoeba dispar are distinct species; clinical, epidemiological and serological evidence. International Journal for Parasitology. 28, pp. 181-186.

Jarallah, H.M. (2016). Contamination of Different Drinking Water Sources with Parasites in Basrah Marshes Villages, Iraq. Journal of Babylon University/Pure and Applied Sciences. 24, pp. 370-376.

Jaykus, L.A., Woolridge, M., Frank, J.M., Miraglia, M., McQuatters-Gollop, A. and Tirado, C. (2009). Climate change: implications for food safety. pp. 49.

Jemli, M., Sabbahi, S. and Ben Ayed, L. (2015). Performance of urban wastewater treatment of four activate sludge treatment plants in Tunisia. International Journal of Water and Wastewater Treatment.

Jiménez-Cisneros, B., Maya-Rendon, C. and Salgado-Velázquez, G. (2001). The elimination of helminth ova, faecal coliforms, Salmonella and protozoan cysts by various physicochemical processes in wastewater and sludge. Water Science and Technology. 43, pp. 179-182.

Kassim, A.H., Morshidy, A., Moayed, J.Y. and Amari, A. (2015). Detection of parasitic contamination in Hilla city drinking water: Babylon provine, Iraq. International Journal of Natural and Applied Sciences. 9(3), pp. 80-84.

Kaur, R., Rawat, D., Kakkar, M., Uppal, B. and Sharma, V.K. (2002). Intestinal parasites in children with diarrhea in Delhi, India. Southeast Asian Journal of Tropical Medicine and Public Health. 33, pp. 725-729. 
Kebede, A., Verweij, J., Dorigo-Zetsma, W., Sanders, E., Messele, T., van Lieshout, L. et al. (2003). Overdiagnosis of amoebiasis in the absence of Entamoeba histolytica among patients presenting with diarrhoea in Wonji and Akaki, Ethiopia. Transactions of the Royal Society of Tropical Medicine and Hygiene. 97, pp. 305-307.

Khairnar, K. and Parija, S.C. (2007). A novel nested multiplex polymerase chain reaction (PCR) assay for differential detection of Entamoeba histolytica, E. moshkovskii and E. dispar DNA in stool samples. BMC Microbiology. 7, pp. 47.

Khairnar, K., Parija, S.C. and Palaniappan, R. (2007). Diagnosis of intestinal amoebiasis by using nested polymerase chain reaction-restriction fragment length polymorphism assay. Journal of Gastroenterology. 42, pp. 631-640.

Khanum, H., Ahmed, S., Uddin, M., Rahman, A., Dey, R. and Farhana, R. (2008). Prevalence of intestinal parasites and anaemia among the slum male children in Dhaka city. International Journal of Biological Sciences.

Kheissin, E.M. and Dmitriev, E.K. (1935). Influence of salts on Entamoeba histolytica cysts. Trudy Leningradskogo Instituta Epidemiologii i Bakteriologii imeni Pastera. 2, pp. 22-31.

Klutse, A. and Baleux, B. (1995). Élimination des oeufs de nématodes et des kystes de protozoaires des eaux usées domestiques par lagunage à microphytes en zone soudano-sahélienne. Revue des sciences de l'eau/Journal of Water Science. 8, pp. 563-577.

Léger, N. (1995). Amibes et amibiases. Maladies infectieuses. pp. 08-500.

Lamps, L.W. (2010). Infectious Causes of Appendicitis. Infectious Disease Clinics of North America. 24(4), pp. 995.

Lauer, W. and Roger, S. (1996). The demonstration of direct potable water reuse: Denver's pioneer project. pp. 25-28.

Lauer, W.C. (1991). Water quality for potable reuse. Water Science and Technology. 23, pp. 2171-2180.

Lawson, L.L., Bailey, J.W., Beeching, N.J., Gurgel, R.G. and Cuevas, L.E. (2004). The stool examination reports amoeba cysts: should you treat in the face of over diagnosis and lack of specificity of light microscopy?. Tropical Doctor. 34, pp. 28-30.

Leong, L. (1983). Removal and inactivation of viruses by treatment processes for potable water and wastewater-a review. Water Science and Technology. 15, pp. 91-114.

Liberti, L., Notarnicola, M. and Petruzzelli, D. (2003). Advanced treatment for municipal wastewater reuse in agriculture. UV disinfection: parasite removal and by-product formation. Desalination. 152, pp. 315-324.

Lim, Y.A.L., Wan Hafiz, W.I. and Nissapatorn, V. (2007). Reduction of Cryptosporidium and Giardia by sewage treatment processes. Tropical Biomedicine. 24, pp. 95-104.

Lippy, E.C. and Waltrip, S.C. (1984). Waterborne disease outbreaks-1946-1980: a thirty-five-year perspective. Journal(American Water Works Association). pp. 60-67.

Lohia, A. (2003). The cell cycle of Entamoeba histolytica. Molecular and Cellular Biochemistry. 253, pp. $217-222$.

Lozano, R., Naghavi, M., Foreman, K., Lim, S., Shibuya, K., Aboyans, V. et al. (2012). Global and regional mortality from 235 causes of death for 20 age groups in 1990 and 2010: a systematic analysis for the Global Burden of Disease Study 2010. Lancet. 380, pp. 2095-2128.

Lucht, E., Evengard, B., Skott, J., Pehrson, P. and Nord, C.E. (1998). Entamoeba gingivalis in human immunodeficiency virus type 1-infected patients with periodontal disease. Clinical Infectious Diseases. 27, pp. 471-473.

Lusk, M., Toor, G.S. and Obreza, T. (2014). Onsite Sewage Treatment and Disposal Systems: Viruses. Series of the Soil and Water Science Department, UF/IFAS Extension.

Maiga, A.H., Konaté, Y., Wethe, J., Denyigba, K., Zoungrana, D. and Togola, L. (2008). Performances épuratoires d'une filière de trois bassins en série de lagunage à microphytes sous climat sahélien: cas de la station de traitement des eaux 
usées de 21E (groupe EIER-ETSHER). Revue des sciences de l'eau/Journal of Water Science. 21, pp. 399-411.

Mai, Z., Ghosh, S., Frisardi, M., Rosenthal, B., Rogers, R. and Samuelson, J. (1999). Hsp60 is targeted to a cryptic mitochondrion-derived organelle ("crypton") in the microaerophilic protozoan parasite Entamoeba histolytica. Molecular and Cellular Biochemistry. 19, pp. 2198-2205.

Makni, F., Sellami, H., Sellami, A., Cheikhrouhou, F., Ayadi, H., Ben Jemaa, M. et al. (2007). L'amibiase viscérale: bilan dans le CHU de Sfax. Revue Tunisienne d'Infectiologie. 1, pp. 20-24.

Malack, M.H., Bukhari, A. and Abuzaid, N.S. (2007). Fate of pathogens in sludge sand drying beds at Qateef, Khobar and Dammam: A case study. International Journal of Environmental Research. 1, pp. 19-27.

Maldonado-Barrera, C.A., Campos-Esparza, M.D., Munoz-Fernandez, L., Victoria-Hernandez, J.A., Campos-Rodriguez, R., Talamas-Rohana, P. et al. (2012). Clinical case of cerebral amebiasis caused by E. histolytica. Parasitology Research. 110, pp. 1291-1296.

McCray, J. (2009). State of the science: review of quantitative tools to determine wastewater soil treatment unit performance.

McLaughlin, J. and Aley, S. (1985). The biochemistry and functional morphology of the Entamoeba. Journal of Protozoology. 32(2), pp. 221-240.

S Mehl, W. and J Ramos, A. (1983). Amibiasis invasora asintomatica en la mujer embarazada. Revista Ginecología y Obstetricia de México. 51, pp. 277-279.

Mirelman, D., Ankri, S., Bracha, R., Katz, U., Libros, P., Nuchamovitz, Y. et al. (Submitted). Molecular dissection of the virulence factors of the human intestinal parasite Entamoeba histolytica. 1997,.

Mohamed, M.A., Siddig, E.E., Elaagip, A.H., Edris, A.M.M. and Nasr, A.A. (2016). Parasitic contamination of fresh vegetables sold at central markets in Khartoum state, Sudan. Annals of Clinical Microbiology and Antimicrobials. 15, pp. 17.

Monge, R., Chinchilla, M. and Reyes, L. (1996). Occurrence of parasites and intestinal bacteria in vegetables that are consumed row in Costa Rica. Revista De Biologia Tropical. 44, pp. 369-375.

Moran, P., Ramos, F., Ramiro, M., Curiel, O., Gonzalez, E., Valadez, A. et al. (2005). Entamoeba histolytica and/or Entamoeba dispar: Infection frequency in HIV+/AIDS patients in Mexico city. Experimental Parasitology. 110, pp. 331-334.

Moreno, A.R. (2006). Climate change and human health in Latin America: drivers, effects, and policies. Regional Environment Change. 6, pp. 157-164.

Mortimer, L. and Chadee, K. (2010). The immunopathogenesis of Entamoeba histolytica. Experimental Parasitology. 126, pp. 366-380.

Murray, C.J.L., Vos, T., Lozano, R., Naghavi, M., Flaxman, A.D., Michaud, C. et al. (2012). Disability-adjusted life years (DALYs) for 291 diseases and injuries in 21 regions, 1990-2010: a systematic analysis for the Global Burden of Disease Study 2010. Lancet (London, England). 380, pp. 2197-2223. doi: 10.1016/S0140-6736(12)61689-4.

Nagakura, K., Tachibana, H., Tanaka, T., Kaneda, Y., Tokunaga, M., Sasao, M. et al. (1989). An outbreak of amebiasis in an institution for the mentally retarded in Japan. Japanese Journal of Medical Science and Biology. 42, pp. 63-76.

National Research Council,. (1994). Ground water recharge using waters of impaired quality. National Academic Press.

Novati, S., Sironi, M., Granata, S., Bruno, A., Gatti, S., Scaglia, M. et al. (1996). Direct sequencing of the PCR amplified SSU rRNA gene of Entamoeba dispar and the design of primers for rapid differentiation from Entamoeba histolytica. Parasitology. 112, pp. 363-369.

Nozaki, T., Kobayashi, S., Takeuchi, T. and Haghighi, A. (2006). Diversity of clinical isolates of Entamoeba histolytica in 
Japan. Archives of Medical Research. 37, pp. 277-279.

Ogbolu, D.O., Alli, O.A., Amoo, A.O.,.., Ilozavbie, G.W. and Olusoga-Ogbolu, F.F. (2011). High-level parasitic contamination of soil sampled in Ibadan metropolis. African Journal of Medicine and Medical Sciences. 40, pp. 321-325.

Ogunlesi, T., Tinuade, O., John, O., Saheed, O., Oyeku, O., Fidelis, N. et al. (2006). Parasitic etiology of childhood diarrhea. Indian Journal of Pediatrics. 73, pp. 1081-1084.

Ogzumus, O.B. and Efe, U. (2007). Distribution of intestinal parasites detected in Camlihemsin healthcare center during the period from July 2005 to January 2007. Türkiye Parazitoloji Dergisi. 31, pp. 142-144.

Ohnishi, K. and Murata, M. (1997). Present characteristics of symptomatic amebiasis due to Entamoeba histolytica in the east-southeast area of Tokyo. Epidemiology and Infection. 119, pp. 363-367.

Omar, M.S., Mahfouz, A.A. and M Moneim, A. (1995). The relationship of water sources and other determinants to prevalence of intestinal protozoal infections in a rural community of Saudi Arabia. Journal of Community Health. 20, pp. $433-440$.

Ottoson, J., Hansen, A., Westrell, T., Johansen, K., Norder, H. and Stenström, T.A. (2006). Removal of noro- and enteroviruses, Giardia cysts, Cryptosporidium oocysts, and fecal indicators at four secondary wastewater treatment plants in Sweden. Water Environmental Research. 78, pp. 828-834.

Oyerinde, J.P., Alonge, A.A., Adegbite-Hollist, A.F. and Ogunbi, O. (1979). The epidemiology of Entamoeba histolytica in a Nigerian urban population. International Journal of Epidemiology. 9, pp. 55-59.

Ozyurt, M., Kurt, O., Yaman, O., Ardic, N. and Haznedaroglu, T. (2007). Evaluation of intestinal parasites in a period of four years in the coprology laboratory of a training hospital. Türkiye Parazitoloji Dergisi. 31, pp. 306-308.

Panicker, P. and Krishnamoorthi, K. (1978). Elimination of enteric parasites during sewage treatment processes. International Association for Water Pollution, Technical Annual. pp. 130-138.

Parija, S.C., Garg, A., Pushpa, K., Khairnar, K. and Priya, T. (2010). Polymerase chain reaction confirmation of diagnosis of intestinal amebiasis in Puducherry. Türkiye Parazitoloji Dergisi. 29, pp. 140-142.

Parija, S.C. and Khairnair, K. (2005). Entamoeba moshkovskii and Entamoeba dispar-associated infections in pondicherry, India. Journal of Health Population and Nutrition. 23, pp. 292-295.

Pazooki, J. and Masoumian, M. (2012). Synopsis of the Parasites in Iranian Freshwater Fishes. Iranian Journal of Fisheries Sciences. 11, pp. 570-589.

American Academy of Pediatrics (2012). Amebiasis. American Academy of Pediatrics. Elk Grove Village, IL.

Petri, Jr, W.A. and Singh, U. (1999). Diagnosis and management of amebiasis. Clinical Infectious Diseases. 29, pp. 1117-1125.

Phiri, J.S., Katebe, R.C., Mzyece, C.C., Shaba, P. and Halwindi, H. (2014). Characterization of biosolids and evaluating the effectiveness of plastic-covered sun drying beds as a biosolids stabilization method in Lusaka, Zambia. Internation Journal of Recycling of Organic Waste in Agriculture. 3, pp. 1-10.

Pinheiro, S.M.B., Carneiro, R.M., Aca, I.S., Irmao, J.I., Morais, M.A., Coimbra, M.R.M. et al. (2004). Determination of the prevalence of Entamoeba histolytica and E-dispar in the Pernambuco state of northeastern Brazil by a polymerase chain reaction. American Journal of Tropical Medicine and Hygiene. 70, pp. 221-224.

Poudel, R.C., Joshi, D.R., Dhakal, N.R. and Karki, A.B. (2010). Anaerobic digestion of sewage sludge mixture for the reduction of indicator and pathogenic microorganisms. Scientific World. 8, pp. 47-50.

Pritt, B.S. and Clark, C.G. (2008). Amebiasis. Mayo Clinic Proceedings. 83, pp. 1154-1159. 
Pulido, M.E. (2005). Evaluation of an electro-disinfection technology as an alternative to chlorination of municipal wastewater effluents.

Rafiei, A., Rahdar, M. and Nourozi, R.V. (2014). Isolation and Identification of Parasitic Protozoa in Sampled Water From the Southwest of Iran. Jundishapur Journal of Health Sciences.

Ralston, K.S. and Petri, Jr, W.A. (2011). Tissue destruction and invasion by Entamoeba histolytica. Trends in Parasitology. 27, pp. 254-263.

Ravdin, J.I. (1995). Amebiasis. Clinical Infectious Diseases. 20, pp. 1453-1464.

Ravdin, J.I., Abd-Alla, M.D., Welles, S.L., Reddy, S. and Jackson, T.F. (2003). Intestinal antilectin immunoglobulin A antibody response and immunity to Entamoeba dispar infection following cure of amebic liver abscess. Infection and Immunity. 71, pp. 6899-6905.

Ravdin, J.I. and Stauffer, W.M. (2005). Entamoeba histolytica (amebiasis). Mandell, Douglas, and Bennett's Principles and Practice of Infectious Diseases. 6th ed. (Mandell, G.L., Bennett, J.E. and Dolin, R., ed.). Churchill Livingstone. Philadelphia, PA.

Rceivala, S., Lakshminarayana, J., Alagarsamy, S. and Sastry, C. (1970). Health aspects. Waste Stabilization Ponds: Design, Construction and Operation in India, Central Public Health Engineering Research Institute, Nagpur, India. pp. 87-95.

Regan, C.S., Yon, L., Hossain, M. and Elsheikha, H.M. (2014). Prevalence of Entamoeba species in captive primates in zoological gardens in the UK. PeerJ. pp. 2.

Reyes, P., Cortés, J., Potdevin, G., Urdaneta, A., Rosales, J., Cuervo, S. et al. (2006). Infecciones en pacientes con trasplante de médula ósea en el trópico. Infection. 10, pp. 101.

Rhallabi, N., Moundib, R., Maaroufy, M., Marghich, M., Khalaayoune, K.H., Bouzooba, K. et al. (1990). Effets des irrigations avec des eaux usées brutes et épurées sur le sol, le rendement d'une culture de tomate et la qualité hygiénique de la récolte. Hassan II Institute of Agronomy and Veterinary Sciences. 10, pp. 57-66.

Rivera, F., Warren, A., Ramirez, E., Decamp, O., Bonilla, P., Gallegos, E. et al. (1995). Removal of pathogens from wastewaters by the root zone method (RZM). Water Science and Technology. 32, pp. 211-218.

Roberts, E.D., Williams, J.C. and Pirie, G. (1973). Naturally occurring gastric amebiasis in the wallaroo. Veterinary Pathology. 10, pp. 323-329.

Royer, T.L., Gilchrist, C., Kabir, M., Arju, T., Ralston, K.S., Haque, R. et al. (2012). Entamoeba bangladeshi nov. sp., Bangladesh. Emerging Infectious Diseases. 18, pp. 1543-1545.

Roy, S., Kabir, M., Mondal, D., Ali, I.K., Petri, Jr, W.A. and Haque, R. (2005). Real-time-PCR assay for diagnosis of Entamoeba histolytica infection. Journal of Clinical Microbiology. 43, pp. 2168-2172.

Saddoud, A., Ellouze, M., Dhouib, A. and Sayadi, S. (2007). Anaerobic membrane bioreactor treatment of domestic wastewater in Tunisia. Desalination. 207, pp. 205-215.

Salaki, J.S., Shirey, J.L. and Strickland, G.T. (1979). Successful treatment of symptomatic Entamoeba polecki infection. The American Journal of Tropical Medicine and Hygiene. 28(2), pp. 190-193.

Salles, J.M., Moraes, L.A. and Salles, M.C. (2003). Hepatic amebiasis. Brazilian Journal of Infectious Diseases. 7, pp. 96-110.

Samie, A., A Bakri, E. and AbuOdeh, R. (2012). Amoebiasis in the Tropics: Epidemiology and Pathogenesis. Current Topics in Tropical Medicine. pp. 202-226.

Samie, A., Barrett, L.J., Bessong, P.O., Ramalivhana, J.N., Mavhandu, L.G., Njayou, M. et al. (2010). Seroprevalence of Entamoeba histolytica in the context of HIV and AIDS: the case of Vhembe district, in South Africa's Limpopo province. 
Annals of Tropical Medicine and Parasitology. 104, pp. 55-63.

Samie, A., Obi, L.A., Bessong, P.O., Stroup, S., Houpt, E. and Guerrant, R.L. (2006). Prevalence and species distribution of E. histolytica and E. dispar in the Venda region, Limpopo, South Africa. American Journal of Tropical Medicine and Hygiene. 75, pp. 565-571.

Schafer, A., Andritsos, N., Karabelas, A.J., Hoek, E.M.V., Scheider, R., Nystrom, M. et al. (2004). Fouling in nanofiltration. Nanofiltration-Principles and Applications. Elsevier. pp. 169-329.

Schuster, F.L. and Visvesvara, G.S. (2004). Opportunistic amoebae: challenges in prophylaxis and treatment. Drug Resistance Updates. 7, pp. 41-51.

Seeto, R.K. and Rockey, D.C. (1999). Amebic liver abscess: epidemiology, clinical features, and outcome. Western journal of medicine. 170, pp. 104.

A Shahrul, T., Mekhlafi, HM.Al, Ghani, MK.Abdul, Azreen, S.N., Salleh, F.M., Ghazali, N. et al. (2012). Different Clinical Outcomes of Entamoeba histolytica in Malaysia: Does Genetic Diversity Exist?. Korean Journal of Parasitology. 51(2), pp. 231-236.

Shalaby, I.M.I., Dewedar, A., Bahgat, M.M.M., Fahmi, M.F. and Salem, M.A.M. (2003). Assessment of the effectiveness of the aerated lagoons system in sewage treatment with reference to the removal of protozoan cysts and helminth eggs. Egyptian Journal of Zoology. 40, pp. 203-224.

Shandera, W.X., Bollam, P., Hashmey, R.H., Athey, P.A., Greenberg, S.B. and White, A.C. (1998). Hepatic amebiasis among patients in a public teaching hospital. Southern Medical Journal. 91, pp. 829-837.

Shanthala, M., Hosetti, B. and Stott, R. (2007). Removal of helminth parasitic eggs from waste stabilization ponds at Shimoga. The BioScan. 2, pp. 9-14.

Sharma, B.K., Rai, S.K., Rai, D.R. and Choudhury, D.R. (2004). Prevalence of intestinal parasitic infestation in schoolchildren in the northeastern part of Kathmandu Valley, Nepal. Southeast Asian Journal of Tropical Medicine and Public Health. 35, pp. 501-505.

Shimokawa, C., Kabir, M., Taniuchi, M., Mondal, D., Kobayashi, S., Ali, I.K. et al. (2012). Entamoeba moshkovskii is associated with diarrhea in infants and causes diarrhea and colitis in mice. The Journal of Infectious Diseases. 206, pp. 744-751.

Singh, U., Rogers, J.B., Mann, B.J. and Petri, Jr, W.A. (1997). Transcription initiation is controlled by three core promoter elements in the hgl5 gene of the protozoan parasite Entamoeba histolytica. Proceedings of the National Academy of Sciences of the United States of America. 94, pp. 8812-8817.

Snow, M., Chen, M., Guo, J., Atkinson, J. and Stanley, Jr, S.L. (2008). Differences in complement-mediated killing of Entamoeba histolytica between men and women-an explanation for the increased susceptibility of men to invasive amebiasis?. The American Journal of Tropical Medicine and Hygiene. 78, pp. 922-923.

Solaymani-Mohammadi, S. and Petri, Jr, W.A. (2008). Intestinal invasion by Entamoeba histolytica. Molecular Mechanisms of Parasite Invasion. pp. 221-232.

Solaymani-Mohammadi, S., Rezaian, M., Babaei, Z., Rajabpour, A., Meamar, A.R., Pourbabai, A.A. et al. (2006). Comparison of a stool antigen detection kit and PCR for diagnosis of Entamoeba histolytica and Entamoeba dispar infections in asymptomatic cyst passers in Iran. Journal of Clinical Microbiology. 44(6), pp. 2258-2261.

Speelman, P., McGlaughlin, R., Kabir, I. and Butler, T. (1987). Differential clinical features and stool findings in shigellosis and amoebic dysentery. Transactions of the Royal Society of Tropical Medicine and Hygiene. 81, pp. 549-551.

Stanley, Jr, S.L. (2003). Amoebiasis. Lancet. 361, pp. 1025-1034.

Stark, D., Barratt, J.L., van Hal, S., Marriott, D., Harkness, J. and Ellis, J.T. (2009). Clinical significance of enteric protozoa 
in the immunosuppressed human population. Clinical Microbiology Reviews.

Stauffer, W., Abd-Alla, M. and Ravdin, J.I. (2006). Prevalence and incidence of Entamoeba histolytica infection in South Africa and Egypt. Archives of Medical Research. 37, pp. 266-269.

Strauss, M. and Blumenthal, U.J. (1990). Human waste use in agriculture and aquaculture. Utilization, practices and health perspectives, executive summary. International Reference Center for Waste Disposal Report. 9, pp. 90.

Subahar, R. and Sutanto, L. (2010). Ascaris lumbricoides Eggs and Human-Intestinal Protozoan Cysts found in River Water of Angke River, Jakarta. Makara Journal of Health Research. pp. 83-85.

Sukpraset, S., Rattapraset, P., Hamzah, Z., Shipin, O. and Chavalistshewinkoon-Pemitr, P. (2008). PCR detection of Entamoeba spp from surface and waste water samples using genus-specific primers. Southeast Asian Journal of Tropical Medicine and Public Health. 39, pp. 6-9.

Tawfik, A., El-Zamel, T., Herrawy, A. and El-Taweel, G. (2015). Fate of parasites and pathogenic bacteria in an anaerobic hybrid reactor followed by downflow hanging sponge system treating domestic wastewater. Environmental Science and Pollution Research International. 22, pp. 12235-12245.

Tefera, T., Biruksew, A., Mekonnen, Z. and Eshetu, T. (2014). Parasitic Contamination of Fruits and Vegetables Collected from Selected Local Markets of Jimma Town, Southwest Ethiopia. International Scholarly Research Notices. 2014, pp. 382715.

Thompson, R.C.A. and Smith, A. (2011). Zoonotic enteric protozoa. Veterinary Parasitology. 182, pp. 70-78.

Tilak, K.V.G.K. (2011). Amoebiasis.

Tomass, Z. and Kidane, D. (2012). Parasitological contamination of wastewater irrigated and raw manure fertilized vegetables in Mekelle city and its suburb, Tigray, Ethiopia. Momona Etiopian Journal of Scence. 4, pp. 77-89.

Tonani, K.A.A., Juliao, F.C., Trevilato, T.M.B., Takayanagui, A.M.M., Bocio, A., Domingo, J.L. et al. (2011). Behavior of Metals, Pathogen Parasites, and Indicator Bacteria in Sewage Effluents During Biological Treatment by Activated Sludge. Biological Trace Element Research. 143, pp. 1193-1201.

Trang, D.T., Hien, B.T.T., Molbak, K., Cam, P.D. and Dalsgaard, A. (2007). Epidemiology and aetiology of diarrhoeal diseases in adults engaged in wastewater-fed agriculture and aquaculture in Hanoi, Vietnam. Tropical Medicine and International Health. 12, pp. 23-33.

Valenzuela, O., Moran, P., Gomez, A., Cordova, K., Corrales, N., Cardoza, J. et al. (2007). Epidemiology of amoebic liver abscess in Mexico: the case of Sonora. Annals of Tropical Medicine and Parasitology. 101, pp. 533-538.

S Vargas, V.da Costa, Bastos, R. and Mara, D.D. (1996). Bacteriological aspects of wastewater irrigation. Monograph No. 8. Leeds University press. England.

Verweij, J.J., Oostvogel, F., Brienen, E.A.T., Nang-Beifubah, A., Ziem, J. and Polderman, A.M. (2003). Short communication: Prevalence of Entamoeba histolytica and Entamoeba dispar in northern Ghana. Tropical Medicine and International Health. 8, pp. 1153-1156.

Vreden, S.G., Visser, L.G., Verweij, J.J., Blotkamp, J., Stuiver, P.C., Aguirre, A. et al. (2000). Outbreak of amebiasis in a family in The Netherlands. Clinical Infectious Diseases. 31, pp. 1101-1104.

Walsh, J.A. (1986). Problems in recognition and diagnosis of amebiasis: estimation of the global magnitude of morbidity and mortality. Review of infectious diseases. 8, pp. 228-238.

Watanabe, K., Gatanaga, H., A de Cadiz, E.-., Tanuma, J., Nozaki, T. and Oka, S. (2011). Amebiasis in HIV-1-Infected Japanese Men: Clinical Features and Response to Therapy. PloS Neglected Tropical Diseases.

Westcot, D. (1997). Quality control wastewater for irrigited crop production. FAO. 
WHO (2006). Volume II of the Guidelines for the safe use of wastewater, excreta and greywater: Wastewater use in agriculture. World Health Organization. France. pp. 196.

WHO, PAHO, UNESCO (1997). A consultation with experts on amoebiasis: Mexico City, Mexico 28-29 January, 1997. Epidemiol Bull. 18, pp. 13-14.

Willhoeft, U. and Tannich, E. (1997). The electrophoretic karyotype of Entamoeba histolytica. Molecular and Biochemical Parasitology. 99, pp. 41-53.

World Health Organization (WHO) (2008). The global burden of disease: 2004 update. WHO. Geneva, Switzerland.

Ximenez, C., Moran, P., Rojas, L., Valadez, A. and Gomez, A. (2009). Reassessment of the epidemiology of amebiasis: state of the art. Infection Genetics and Evolution. 9, pp. 1023-1032.

Yakoob, J., Abbas, Z., Beg, M.A., Naz, S., Khan, R. and Jafri, W. (2012). Entamoeba species associated with chronic diarrhoea in Pakistan. Epidemiology and Infection. 140, pp. 323-328.

Yousefi, Z. and Hezarjaribi, H.Z. (2013). Elimination of Nematode Cysts and Ova from Hospital Sewage by Activated Sludge Process. Iranica Journal of Energy and Environment.

Yousefi, Z., Hezarjaribi, H.Z., Enayati, A.A. and Mohammadpoor, R.A. (2009). Parasitic Contamination of Wells Drinking Water in Mazandaran Province. Iranian Journal of Environmental Health Science and Engineering. 6, pp. 241-246.

Zahida, T., Shabana, K. and Lahsari, M.H. (2010). Prevalence of Entamoeba histolytica in humans. Pakistan Journal of Pharmaceutical Sciences. 23, pp. 344-348.

Zhang, T., Cieslak, P.R., Foster, L., Kunz-Jenkins, C. and Stanley, Jr, S.L. (1994). Antibodies to the serine rich Entamoeba histolytica protein (SREHP) prevent amoebic liver abscess in severe combined immunodeficient (SCID) mice. Parasite Immunology. 16, pp. 225-230.

Ziaie, H.H., Yousefi, Z. and Mohammadpour, T.R. (2006). Parasitic contamination of wells drinking water in Mazandaran Province in 2002-2003. 